\title{
A remény pszichológiája. Elméleti áttekintés az empíria tükrében
}

\author{
KIS MÉDEA* \\ Tiszántúli Református Egyházkerület, Pasztorációs Intézet, Debrecen \\ Debreceni Egyetem, Népegészségügyi Kar, Megelőző Orvostani Intézet, Debrecen
}

(Beérkezett: 2016. január 24.; elfogadva: 2016. július 13.)

\begin{abstract}
E tanulmány célja magyar nyelven összefoglalást adni a remény mint lélektani konstruktum elméleti hátteréről, vizsgálati módszereiről, különféle megközelítések, hangsúlyos kutatási irányok egybevetésével, továbbá integratív igényú definíciót kínálni a nemzetközi és hazai eredmények figyelembe vételével. Az eredmények gyakorlati hasznosíthatósága is kifejtésre kerül. A remény mint személyiségjellemző a jövendőre, és az egyén számára értékes, de nem túl távoli cél elérésére irányuló várakozás, amelyet általában a nem kielégítő jelen állapot indukál. A reményteliség szintje érzelmi, kognitív, motivációs, viselkedéses és környezeti összetevói révén növelhető. Szerepe a kapcsolati kommunikáció gazdagságában, a munka-, szellemi, és sportteljesítményben, és nem utolsó sorban a betegségekból felgyógyulás és a poszttraumás növekedés folyamatában érhető tetten.
\end{abstract}

Kulcsszavak: remény, reményteliség, reménytelenség, empirikus kutatások, gyakorlati intervenciók

\section{Bevezetés}

Amikor a remény pszichológiáját kutatjuk, alapvető lelki mozgatóink egyikét próbáljuk tetten érni. A remény mint lélektani konstruktum a múlt század hetvenes éveiben önállósul, előrajzolódva a filozófiai és a teológiai megközelítések hátteréből. Egyes tartalmi összetevőinek - mint a jövendőre irányultság, a pozitív érzelmek és beállítódások, vagy a kreatív megküzdés tudományos igényú kutatása az új évezred beköszöntével lett otthonossá a szakirodalomban (Abi-Nashem, 2001; Seligman \& Csíkszentmihályi, 2000). A humanisztikus pszichológia jeles képviselőinek (A. Maslow, C. Rogers) a személyiségben rejlő adottságokat, erőforrásokat és növekedési esélyeket előtérbe helyező szemlélete már ezt megelőzően inspirálta a tudományos érdeklődést olyan fogalmak kutatására, amelyeket a lélektan addig nem tekintett eléggé egzaktnak. Ezt követően azonban néhány évtized alatt jelentékeny számú közlemény járult hozzá a remény pszichológiai fogalomként

\footnotetext{
* Levelezési cím: dr. Kis Médea, Tiszántúli Református Egyházkerület, Pasztorációs Intézet, 4026 Debrecen, Fúvészkert u. 4. E-mail: kis.medea@ttre.hu
} 
értelmezéséhez. Az emberi erősségek tudományos kutathatóságát és osztályozhatóságát felvállaló pozitív pszichológia az életminóség célirányos viselkedéssel kapcsolatos összetevőjeként tartja számon (Snyder, Rand, \& Sigmon, 2005). A transzperszonális pszichológia eszmerendszere pedig (Bagdy, 1996), a létről, megismerésról és az ember lényegéről formált nézeteivel egy termékeny szellemi táptalajt nyújt a remény fogalma jelentőségének újragondolásához.

Több kérdéssel szembesül azonban, aki szeretné leírni e lélektani jelenséget. Tisztázandó a tárgyalni kívánt fogalmi mező, tehát egyrészről az, hogy a remény a reményteliség szinonimája-e, illetve, hogy az előbbi hiányában beszélünk-e reménytelenségről. Ilyen módon a remény és reménytelenség egymás egyszerú ellentétei lennének. Megválaszolandó a továbbiakban, hogy remény és reménytelenség egyazon dimenzió két végpontját jelentik-e, mint pozitív várakozások, illetve negatív várakozások a jövőre vonatkozóan. Pontosabb lehet a fogalomhasználat és egyértelmúbb a további kifejtés, ha a reményteliséget a remény mértékének, magasabb szintjének értelmében használjuk, a remény mint alapfogalom pedig annak megvalósultsága. Arra is érdemes keresni a választ, hogy a remény személyiségvonás-e vagy szubjektív élmény. Amennyiben személyes hatóeró jellegét, a kívánt cél megvalósításához szükséges belső motiváció erősségét vizsgáljuk, úgy az előbbi, amennyiben a célok önvezérelt és hatékony elérésének becsült valószínúségeként értelmezzük, úgy inkább az utóbbi.

Áttekintő elméleti tanulmány magyar nyelven korábban e témában nem született, mint Magyaródi (2012) megállapítja. Martos, Lakatos és Tóth-Vajna (2014), a konstruktum mérésére irányuló, pszichometriai vizsgálatai nyomán azonban jelentékeny friss, hazai adatra tettünk szert. Jelen tanulmány célja tehát a remény lélektana elméleti, módszertani és gyakorlati vonatkozásainak fókuszba helyezése, és egy integratív definíció eloállítása.

\section{Elméleti áttekintés}

\subsection{A remény konceptualizálása}

A nemzetközi szakirodalomban igen nagy számban állnak rendelkezésre olyan klinikai kutatási eredmények, amelyek a reményt a személy betegségre adott válaszaként próbálták megragadni (Glawischnig-Goschnik, 2010). Mérhetősége is a gyógyulás szempontjából vált fontossá (Hinds, 1988). Vizsgálták továbbá a remény jelentőségét a testi betegségből felépülés során, a betegség ellenére vagy éppen a betegség közepette megélt életminőség összefüggésében (Rustøen, 1995) is. 
Pszichiátriai tapasztalatok szerint elsősorban a remény hiánya mutat rá a remény jelentőségére (Farran, Herth, \& Popovich, 1995, idézi Snyder, 2000a). Szerepe tehát empirikus megközelítés révén szembetúnő a kutató számára, ám elméleti leírásakor egyre komplexebb modellek megalkotása látszott célravezetőnek. Áttekintésüket bonyolítja, hogy az egyes szerzóknél a fogalom különféle értelmezéseivel találkozunk. A remény mint állapot (reménykedni valamiben), a remény mint megküzdés, illetve a reménykedésre való hajlam mint személyiségvonás egyaránt képviseltetve van a különböző megközelítésekben. Ezeknek a konstruktumoknak a viszonylagos elkülönítését is megkísérli a jelen tanulmány.

\subsubsection{Egyfaktoros modellek}

A korai, egyfaktoros reményértelmezések között különbséget tehetünk aszerint, hogy érzelemfókuszú, érzelmi-kognitív, vagy kognitív fókuszú modellel van-e dolgunk. Lynch (1965) emócióként határozza meg, mint annak elemi érzetét, miszerint lehetséges összeegyeztetni a külső és a belső realitást, és van kiút a bonyolult helyzetekből. Érzelemként kezeli elsőrenden Lazarus (1999) is, aki szerint a remény meggyőződés afelől, hogy valami pozitív tényező, ami a jelenben még nem része az életnek, egyszerre kézzelfoghatóvá válhat, ezért az ember törekszik az elérésére. Mint érzelmet, nem könnyú kontrollálni, sőt befolyással vannak rá a társas hatások is. E megközelítések megegyeznek abban, hogy a remény létrejöttének előzménye, feltétele az aktuális körülményekkel való elégedetlenség. Eszerint bizonyos vágy ébreszti, mégpedig egy másféle helyzetben lenni végre, és az a benyomás táplálja, hogy egyéni erőfeszítés vagy külső változás hatására elérhető. Érzelmi-kognitív jellegúnek tekinti Obayuwana és Carter (1982), szerintük a remény egy, az éneró folytán létrejövő elmeállapot, amely énerő a hatékony énvédő mechanizmusok, a neveltetés, a családi társas támogatás, a vallásosság és anyagi javak együtteséből ered (ún. reménypentagram). Fenti meghatározások esetében a mérhetőség nem jellemző szempont.

A kognitív fókuszú koncepciók közül legkorábbi a Stotlandé (1969, idézi Erickson, Post, \& Paige, 1975), akinél a remény lényege valamely cél eredményes elérésének várása, mértéke pedig a célelérés szubjektív valószínúségének mértékével arányos. A reményteliség szerinte az adaptív viselkedés egy faktora. A reménytelenséget összefüggésbe hozta a mentális betegségekkel, míg a gyógyulást a reményteliség helyreállításával (Erickson és mtsai, 1975). Kognitív fókuszú Hinds (1984) megközelítése is, aki egyidejúleg törekedve a konstruktum elméleti megragadására és egy induktív úton kifejlesztett méróeszköz létrehozására (Hopefulness Scale for Adolescents), sokkal tágabb jelentéstartalommal az egyéni jövő elővételezését érti alatta. 
Averill, Catlin és Cohn (1990) nyomán a remény kognitív szabályok irányítása alatt álló érzelmi jellegú jelenség, ahol azonban társadalmi normák befolyásolják, hogy mennyire jelentős egy adott cél az egyén számára, mekkora lesz a várt esemény bekövetkeztének a vélt valószínúsége, és milyen mértékú az esemény bekövetkeztének személyes vagy szituatív kontrollja. Megnevezik a remény létrejöttének szabályszerúségeit is, miszerint a remény tárgya realisztikus kell legyen (prudential rules), a reménylett dolog nem lehet a társadalom értékrendjével ellenkező (moralistic rules), továbbá elemi érdek kell kapcsolódjon hozzá (priority rules). Ha ugyanis nem elég fontos a remény tárgya, akkor az elővigyázatossági és az erkölcsi alapelvek is jelentőségüket vesztik. Végül szükséges a cselekvésre készség azon dolgok véghezvitelére, amelyek a remélt dolog bekövetkeztét elősegítik, és amelyek egyúttal a személyes kontrollt is biztosítják (action rules). Megemlítendő, hogy ebben a szemléletben egy másik személybe vetett bizalom vagy az ima is aktív cselekvésként jelenik meg. A szerzők hangsúlyozzák, hogy a mindenkori reménykoncepció implikálja a kor és az adott társadalom meghatározó spirituális és morális értékeit. E modellt Snyder (1995) ugyanakkor úgy értékeli, mint érzelmi hangsúlyú megközelítést, amely szerint az emóciók irányítják a kogníciót a társas szempontból értékesnek tekintett célok elérése érdekében. A német Huppmann (2006) arra mutat rá, hogy a remény hatása a magatartás szintjén is megjelenik, amikor is a személy viselkedését valamely, gondolati szinten megelőlegezett kedvező jövőbeni esemény határozza meg. Izard (1981) álláspontját követve úgy véli, alapvető különbség mutatható ki az emberek között attól függően, hogy valaki pozitív vagy negatív kimenetelú események bekövetkeztét várja.

\subsubsection{Szituatív modellek}

Hammelstein és Roth (2002) értékelméleti megközelítésében a remény egyaránt bír helyzeti és személyi összetevőkkel, fóként alapvető szükségletekhez kapcsolódó célok akadályoztatása esetén jut szerephez, és olyan konkrét dologra irányul, amelynek bekövetkezte vagy be nem következte hatással van az értéktudatra. Céljától függően eltérő mérőeszközökkel mérhető. Brodda (2006) egy folyamatmodellben vázolja a remény lassan kifejlődő, de viszonylag stabil pozitív érzelmi állapot jellegét, amelynek külső megnyilvánulása csekély, azonban azáltal, hogy a vágy tárgyát időben közelebb hozza, elérhetőnek láttatja, bizonyos mértékú elégedettségérzetet kelt. A remény magas szintje mellett a személy motivált lelkiállapotba kerül, és egy pót-, vagy elókielégüléshez jut. A kognitív összetevő, amely a várt esemény bekövetkeztének érzetét a megvalósulásnak mindig legalább a minimális 
szintjén tartja, egyfajta belső biztonságérzetet eredményez. A remény e modell szerint alapvetóen szubjektív, személyes beállítottság, ami valami objektívre, külső eseményre vagy személyre, mint a vágy tárgyára irányul.

\subsubsection{Vonásalapú modellek}

A vonásalapú megközelítés a reményt jellemzően a megküzdési mechanizmusokkal hozza kapcsolatba, különös tekintettel a személyes sikerekre, illetve hibákra (Szondy, 2008). E konstruktum esetében is igaz, hogy mint megküzdés, szokásokra illetve stratégiákra vonatkozik, amelyekből idővel egy vonás integrálódik, vagy amelyeket egy vonás „mozgat”. Rustøen (1995) szerint a remény kifejezetten egyfajta megküzdési stratégiának tekinthetô, és mint belső diszpozíció lehetővé teszi, hogy a személy megbirkózzon a szenvedéssel, bonyolult, stresszteli helyzetekkel, ekként az adaptív viselkedés és az életminőség összetevője. Seligman $(2008,135$. o.) úgy jellemzi a reményteli embereket, mint akik tartós okokkal és „generalizáltan magyarázzák a jó eseményeket, ugyanakkor specifikusnak és ideiglenesnek tekintik a rossz eseményeket, gyorsan talpra állnak a bajokból, és könnyen lendületbe jönnek, amikor sikert érnek el". A remény a Big Five faktorai közül a lelkiismeretességgel mutatja a legszorosabb összefüggést, ami magyarázható azzal, hogy mint vonás a célelérésre reflektál (Halama \& Dedová, 2007).

\subsubsection{Integratív modellek}

Integratívnak tekinthető Scioli és munkatársainak (Scioli, Chamberlin, Samor, Lapointe, Campbell, Macleod, \& McLenon, 1997; Scioli, MacNeil, Partridge, Tinker, \& Hawkins, 2012) modellje, amely ugyan elsósorban érzelemként kezeli, de egy érzelmi hálózatként ragadja meg a reményt, ami biológiai, pszichológiai és társas elemekból épül fel, és kontrolligényt, kapcsolati, spirituális, valamint a túlélésre irányuló motívumokat foglal magában.

A bécsi pszichiáter, Beate Schrank és munkatársainak (2008) szakirodalomelemzése egy világos koncepció ajánlatával, az időszerúség, alkalmazhatóság és a tudományos érvényesség bizonyításával járul hozzá a konstruktum leírásához. Metaanalízisük összesen 49 kvalitatív kutatás, valamint válogatott tanulmányok áttekintése nyomán előállított definíciót azonosít, és 32 méróeszközt vesz szemügyre. A meghatározások közös eleme, hogy a remény egyéni attribúciókra épülő pozitív beállitódás: az elmének egy adott motivációs és érzelmi állapota, lendületet adó életenergia, pozitív meggyő- 
ződés, a jövendő elővételezése (anticipáció), az alkalmasságérzés (empowerment) összetevője, az optimizmus fokmérője, leginkább pedig várakozás (expectation). E meghatározások alapján dinamikus, és bizonyos határokon belül változékony személyiségjellemzőről van szó, amelynek ugyanúgy serkentője lehet a jelen kellemetlen állapot, mint az eredményes megküzdés múltbéli tapasztalata. Olyan, az egyén számára értékes célokhoz kapcsolódik, amelyeket a személy potenciálisan megvalósíthatónak ítél. Elméleti alapon a remény hét fő dimenzióját különítik el: idő, kezdőpont, célok, az eredmény valószínúsége, kontrollhely, egyéb változókkal való kapcsolat, személyes jellemzók. A remény személyes jelentéssel ruházza fel az élettörténeti eseményeket. Sajátos időbeli kölcsönhatás jellemzi, amely szerint nem csupán a múltbéli tapasztalatok vannak hatással a jövóbeni elvárásokra, hanem ami a jövendőben remélhetőnek túnik, befolyásolja a múlt értékelését is. Öszszegző definíciójuk szerint a remény egy jövendôre irányuló elvárás, amely értékesnek itélt célok, kapcsolatok vagy a spiritualitás összefüggésében értelmezendő (Schrank és mtsai, 2008. 426. o.).

\subsubsection{Többfaktoros modellek}

Az eddigi eredmények szerint tehát a remény esetében is egyértelmúen kimutatható és megkülönböztethetó a diszpozícionális, (trait) valamint a szituatív (state) jelleg (Schrank, Woppmann, Sibitz, \& Lauber, 2011). A többfaktoros modellek képesek a leginkább megragadni a remény konstruktumának összetettségét.

Elméleti megfontolások alapján dinamikus és multidimenzionális életeróként értelmezi a reményt Dufault és Martocchio (1985), amely az egyén számára jelentős és valós célra irányul, és bizonytalanság ellenére is bizakodással tölti el a személyt. Modelljük a remény két fő területét, „„szféráját" és hat dimenzióját különíti el. Az általános szféra, a tulajdonképpeni vonásreménység az a föltételezés, hogy a jövendó kedvező lesz. Az élettel szembeni olyan alapvető attitúd, ami nem kötődik közvetlenül egy adott tárgyhoz vagy eseményhez. Ezzel szemben a remény speciális szférája arra az adott állapotra vonatkozik, amikor a remény konkrét vagy elvont tárgyra irányul. A szerzők szerint mindkét szférán belül hat összetevő jelenik meg, amelyek kölcsönhatásban állnak, bár nem feltétlenül van jelen mindegyik mindenkor: 1. affektív (érzelmek, érzetek, feltételezések), 2. kognitív (a remélt dolog valószerúségének felülvizsgálata), 3. viselkedéses (lelki, testi, társas, vallásos cselekvések), 4. affiliatív (kapcsolódás egy másik személyhez vagy istenhez), 5. időbeli (rövid- vagy hosszútávú célok, korábbi tapasztalatok kihatásai), 6. kontextuális (adott szituáció, amelyben a reménynek fontos szerep jut). Eszerint a két „szféra” megkülönböztethető bár, de nem függet- 
len egymástól. Ezt támasztja alá Ziv, Chaim és Itamar (2011) vizsgálata, amely azon kritikus pillanatot próbálta megragadni, amikor valamiféle akadály elóállása okán a remény szerephez juthat. A vizsgálatukban résztvevó 60 személy fele, miután kitöltött egy diszpozicionális remény skálát, hibaüzeneteket kapott a számítógépén, majd kellemes zenei élményben részesült, míg a másik csoport nem. Ezt követően mérték a kísérleti személyek pozitív illetve negatív érzéseinek mértékét, valamint az állapotreménységet. Szemben a kontrollcsoporttal, a kellemes zene szignifikánsan emelte a helyzetben megmutatkozó remény szintjét, a vonásreményre azonban nem volt érdemi hatással. A zene és a diszpozicionális remény között azonban mégis kimutatható volt közvetett összefüggés. Azon személyek állapotreménységére volt szignifikáns hatással a pozitív zenei élmény, akik egyébként is magasabb vonásremény-szinttel rendelkeztek, tehát általában reménytelibbek voltak helyzettól és időtól függetlenül, míg a reménytelenséggel inkább jellemezhetó személyekre nem gyakorolt kimutatható hatást.

Az orvosi pszichológia empirikus adatokra támaszkodva kutatja a remény összetevőit (Farran, Herth, \& Popovich, 1999). Nekolaichuk, Jevne és Maguire (1999) kérdőíves vizsgálat alapján $(n=550)$ három faktort mutatott ki az egészség és betegség összefüggésében. Eszerint a domináns személyes összetevő a jelentés témája köré szerveződik, szubjektív és értékeló jellegú. A második a kockázat, mint bejósolható helyzeti tényező, ami életbátorságra készteti a reményteli személyt. A harmadik a hitelesség és a komfortérzet fenntartását magában hordozó személyközi összetevő.

A pozitív pszichológia szemléleti keretén belül, annak mintegy úttörőjeként alkotta meg modelljét Snyder (Snyder, 2000a; Snyder, 2000c; Snyder és mtsai, 2005b), aki az 1990-es évek kezdetétól foglalkozott a remény kérdésével. Eredményei szerint a reményteli személy fó jellemzői, hogy 1. pozitív célokat tud kitúzni, amelyeket semmiképp nem téveszt szem elől, 2. képes a dolgoknak a maga számára előnyös kimeneteléért erőfeszítéseket tenni, és 3. szükség esetén a célhoz közelebb jutás új ösvényeit megtalálni. A célok lehetnek rövid- vagy hosszútávúak, de mindenképp elég értékesnek kell lenniük az egyén számára, mert akkor mozgatják meg tudatos gondolkodását. Ilyen módon a célok és a célhoz vezető ösvények kreatív kialakítására irányuló gondolatok jelentik a remény kognitív összetevójét (Snyder, Cheavens, \& Sympson, 1997a). Megkülönböztetik emellett a motivációs öszszetevőt, amely a kitúzött cél felé törekvésnek saját becsült kapacitása, az érzelmi összetevő pedig a személy észlelt reménysége mértékének megfelelően jelentkezik (Snyder, 1995). A gondolatok elsőbbséget élveznek az érzelmekkel szemben, az érzelmek a cél közeli vagy távoli voltának függvényében ébrednek. Akadállyal szembesülve a céleléréshez szükséges motiváció újraszerveződik. Kutatási eredmények támasztják alá, hogy akiknél a remény magasabb értékeit mérték, bonyolultabb célokat túztek maguk elé, 
és akadály esetén hatékonyabbnak bizonyultak alternatív megoldások keresésében (Irving, Snyder, \& Crowson Jr., 1998; Snyder és mtsai, 1991). Megközelítésük alapján a reményt egy pozitívan motivált lelkiállapotként, ugyanakkor valamely cél elérésére irányuló kognitív konstruktumként lehet meghatározni (Snyder, 1995). E modell összefüggésében a reményteli személy egyrészt úgy tekint önmagára, mint aki személyes hatóerővel rendelkezik, amelynek segítségével saját sorsa alakításában aktívan közremúködik, és mivel már a múltban és a jelenben sikeresen elérte kitúzött céljait, a jövőben is ezt tételezi fel önmagáról (agency = személyes hatóerö, ágencia). Másrészt úgy, mint aki képes távlatosan gondolkodni, célokat felfedezni, és a vágyott célhoz vezető ösvényeket meglelni vagy megtervezni, megtapasztalván korábbi eredményességét (pathways thinking = megoldási lehetőségek). E két összetevő egymást kiegészíti, folyamatos egymásra hatás által fölerősíti. Az e forrásokból származó, a remény által meghatározott gondolatok szekvenciálisan ismétlődnek az idő függvényében, és alterálnak az érzelmek és kiértékelések következtében. Martos és munkatársai (2014) kutatásai arra mutatnak rá, hogy a megoldási módok ismerete elsősorban nem önmagában, hanem a megvalósításhoz kapcsolódó belső motiváción keresztül játszik szerepet a személyiség múködésében. Jelentős tényező továbbá maga a vágyott cél (goal), amely tipikusan akkor a leginkább reményt keltő, ha különleges, de elérhető, emellett sem túl távoli, sem túl közeli. A személyes célok kulcsfontosságú funkciója Martos és Kézdy (2007) szerint abban áll, hogy vezérlik a személy viselkedését. Mint mentálisan reprezentált kimeneti állapotok vagy referenciaértékek meghatározzák a cselekvések szubjektív értelmét. Elérhetőek a tudatosság szintjén, befolyásolják az aktuális gondolatok tartalmát, irányát és energiaszintjét, érzelmek formájában pedig visszajelzést adnak arról, hogy hol tart az egyén céljai elérésében. Integratív erővel bírnak, többé-kevésbé jól összehangolt összeköttetést biztosítva a személyiségjellemzők és a személy belső elvárásai, tudatosan követett értékei és tudattalan motivációi, valamint a környezeti tapasztalatok és lehetőségek között. Amikor úgy túnik, hogy a személynek nincs lehetősége tennie önmagáért, akkor a reménynek köszönhetóen viseli el a változtathatatlant, mint ezt $V$. E. Frankl (1982) szenvedések között fogant gondolatai illusztrálják. Frankl amellett foglal állást, hogy az emberi létnek minden körülmények között értelme van, és ennek megtalálása mint életcél a legkülönfélébb utakon át lehetséges, akár a koncentrációs tábor kilátástalan és embertelen körülményei közepette is. Huen, Ip, Ho és Yip (2015) szerint a célnak és a célelérést megelőző gondolkodási folyamatnak a hangsúlyozása adja a snyder-i modell azon sajátosságát, amely a korábbiaktól megkülönbözteti.

A vonásreménység immár klasszikusnak tekinthető snyder-i megközelítése időközben többeket inspirált vitára, vagy a modell továbbfejlesztésére. Kultúrközi kutatások perspektívájából például (Du \& King, 2013) túl indi- 
vidualisztikus, mivel lehorgonyoz az egyén belső diszpozíciójánál, elsősorban a remény belső forrásaira fókuszál. Bernardo (2010) viszont továbbfejleszti Snyder diszpozícionális remény koncepcióját, azon belül is a személyes hatóerő (agency) faktort veszi górcső alá. Megkülönbözteti a remény belső és külső forrásait (internal/external locus-of-hope), amelyek egymástól eltérő utak megtalálását generálják a vágyott cél eléréséhez. Mint kifejti, a személyes hatóerő támaszkodhat vagy hivatkozhat külső ágensekre is, lehet egy jelentós másik személy, a család, a kortársak, vagy valamely transzcendens létező, spirituális tényező, amely a személy számára realitással bír. Kezdetben megfigyelésen alapuló elméleti modelljét empirikusan is ellenórizte, és ez alapján azt állapította meg, hogy a remény külső, illetve belső forrásai összefüggést mutatnak a kollektivizmus-individualizmus dimenzióval. Bernardo dimenzionális megközelítésen túlmutató holisztikus szemlélete utat nyit a társas alapú koncepciók felé.

\subsubsection{Társas alapú megközelitések}

A hazai szakirodalomban a remény konstrukciójának történelmi-kulturális beágyazottsága túnik elő, mivel kevésbé individuális élményként, sokkal inkább csoportalapú érzelemként jelenik meg. Nemzetkarakterológiai elméletek illetve történelmi események érzelmi aspektusainak vizsgálata a reményt a társadalom-lélektani kutatások fókuszába helyezi. Bibó István (2004/1948) hét évtizeddel ezelőtt mutatott rá arra, hogy döntő történeti pillanatokban az ország végzetes módon képtelennek bizonyult saját helyzetének valóságos adottságait meglátni és az ebből fakadó feladatokat felismerni. Mintha a korábban lelkesedő, önérzetes nemzet reményét vesztette volna.

Fülöp és munkatársai a magyar nemzeti identitás érzelmi szerveződését vizsgálják. Történelmi regények (Fülöp, Péley, \& László, 2011), valamint történelemkönyvek és néphistóriai narratívumok (László \& Fülöp, 2010) pszichológiai tartalomelemzése útján valós történelmi eseményekhez kapcsolódóan tárják fel azt az érzelmi mintázatot, amely idővel a nemzeti identitás részévé vált. A László (2008) által bevezetett történelmi pályaérzelmek fogalmát használják, értve ez alatt azokat az emóciókat, amelyek egy adott nemzetre jellemzóvé válnak a történelmi események értékelése nyomán, az azokra adott egyfajta érzelmi válaszkészség formájában, és konzekvensen visszatérő érzelmeknek tekinthetők a történelmi reprezentációkban. Vizsgálati eredményeik szerint a remény konstrukciójának angolszász hagyományával szemben (kognitív elóvételezés és aktív megküzdés) a magyar kultúrában a remény negatív érzelemmel, konkrétan csalódottsággal és passzív copinggal párosul. Úgy találták, hogy a magyar történelmi pályához kap- 
csolódó érzelmek különleges alakzatot hoznak létre, amelyben félelem, remény, lelkesedés, szomorúság, csalódás és szenvedés együttes megjelenése figyelhető meg, továbbá, hogy ezek az érzelmek teljes mértékben megfelelnek a Bibó által a magyar lelkiállapotot történelmi illuzionizmussal és politikai hisztériára való hajlamossággal jellemző elemzéseknek (Fülöp \& László, 2011). Véleményük szerint az érzelmek ilyen dinamikus mintázata arra mutat rá, hogy az egyes érzelmeket nem érthetjük meg a társas-társadalmi kontextus figyelembe vétele nélkül. Amit a „remény” címkével illetünk, annak különféle jelentése lehet az eltérő történelmi pályák kontextusában. „A magyarok reménye a sorozatos kudarcok nyomán lép fel, és abbéli hitüket jelzi, hogy a dolgok mégis pozitív fordulatot vesznek. Az amerikaiak reménye a jóvátételhez illeszkedik, egy optimista életszemlélethez, míg Izrael esetében a remény a tudatos megküzdés megnyilvánulása. Mindegyik érzés az adott nemzet narratív identitásstruktúrájából vezethető le" (Fülöp \& László, 2011. 479. o.). A szerzők úgy ítélik, hogy a magyar haza alapjait érintő veszteségek sorozata a nemzet élményszerveződésének központi magjává vált. Az állandó létért való harc jelentős következményekkel járt a közösség kognitív-érzelmi múködését tekintve. Az irreális területi elképzelésekhez való ragaszkodás, a visszaszerzéshez fúzött remények beteljesedésének hiánya szükségszerúen csalódásokhoz, egyfajta depresszív beállítódáshoz vezetett. A magyaroknál megjelenö remény tehát a sok csapást elszenvedettek bizakodását jelenti abban, hogy többé nem éri óket hasonló megrázkódtatás, és közelebb kerülhetnek a vágyott célokhoz, sőt kiléphetnek a rögzült, torz megoldási módok nyomvonaláról (László \& Fülöp, 2010).

A nemzetközi kutatások eredményei alapján a közös remény támogatólag hat az egyén reménységének szintjére (Snyder és mtsai, 1997a), illetve a több társas támogatás a reményteliség magasabb fokát eredményezi (Gestel-Timmermans, Bogaard, Brouwers, Herth, \& Nieuwenhuize, 2010). Figyelembe véve azt a Kulcsár, Rózsa és Reinhardt (2006) által leírt jelenséget, amely szerint az énérzés és az egységérzés igen nehezen elkülöníthetó funkciók, föltételezhetjük, hogy a másik akcióinak észlelése és saját akcióink kivitelezése a remény szocializációja során is kölcsönhatásban áll. Mivel az én és a másik reprezentációjának teljes mértékben el nem választható mivolta a neurális történések szintjén alapozódik meg (Kulcsár, 2005), az egyén feltehetóleg úgy tanul meg reménykedni, hogy azt a legközelebbi társas kapcsolatai közvetítik számára, és hogy milyen mértékben reményteli, abban meghatározó a szerepe annak a családi, baráti, egyházi, nemzeti, spirituális környezetnek, mellyel azonosul, amelyhez tartozónak tekinti magát (Du \& King, 2013).

Howell és Larsen (2015) koncepciója abból indul ki, hogy a remény nem az egyén saját szerencséjének elérésére irányul, hanem az embertárs javát túzi ki célul, aki nem más, mint a jelentős másik, akivel a személy közeli 
kapcsolatban áll. A „vikariáló remény” nem az egoszisztéma, hanem az ökoszisztéma része és fenntartója. Tartalma kerül előtérbe sokkal inkább, mint folyamat jellege. A másikra irányuló remény egy jövőorientált hit, vágy és mentális képalkotás a másik személy sorsának valamely érték által meghatározott alakulásáról, amely kimenet bizonytalan bár, de lehetséges.

2.2. A remény fogalmának tartalmi elkülönítése és elhelyezése

\subsubsection{Optimizmus és remény}

Sokáig tartotta magát a vélemény, miszerint a két fogalom ugyanarra a jelenségre vonatkozik, és egymástól nem megkülönböztethetőek (Tiger, 1979). Kétségtelen, hogy a diszpozicionális optimizmus és a diszpozicionális remény, e két, egymáshoz közel álló konstruktum közös jellemzője azok jövendőre irányuló volta. Az optimizmus és a remény hasonlóképp stabil személyiségvonásként egyaránt a személy boldogabb jövendőjének elérkeztére reflektál. Az optimizmus egy kognitív változó, a remény inkább érzelem, kognitív összetevőkkel (Scioli és mtsai, 1997). Együttjárásuk szignifikáns (Wong \& Lim, 2009). Mindkettő tekinthető úgy, mint egy elérésre érdemes célt implikáló célattitúd. Rand (2009) szerint csupán a funkció eltérő, amenynyiben a remény a selfre, az optimizmus a világra fókuszál. Shorey, Little, Snyder, Kluck és Robitschek (2007) eredményei szerint a remény az optimizmus szignifikáns prediktora.

A reményteliség nemcsak hétköznapi megjelenésében mutat hasonlóságot az optimizmussal, e jellemzők a személyiség szintjén is kimutatható öszszefüggésben állnak. Minkettő felfogható olyan diszpozícióként, amelynek fontos viselkedésbeli következményei vannak, amelyek kihatnak az egészségmagatartásra és a betegségmagatartásra. Vizsgálatok támasztják alá, hogy a magasabb optimizmusszint kevesebb testi tünettel, rövidebb gyógyulási idővel és a mortalitási rizikó csökkenésével jár együtt (Bérdi \& Köteles, 2010). A remény-egészség kapcsolat tekintetében ugyancsak bizonyítást nyert, hogy a remény alacsony szintje különféle betegségek megjelenésével és gyakoriságával áll összefüggésben (Scioli és mtsai, 1997).

Mindkettő előjelzője az élettel való elégedettségnek (Rand, Martin, \& Shea, 2011), de a depressziónak is (Wong \& Lim, 2009). A két konstruktum tehát egyaránt adaptációs jelentőséggel bír. Ugyanakkor, mint Martos és munkatársainak (2014) kutatásai is igazolják, a Remény Skála (AHS-H) az optimizmustól jól elkülöníthető konstruktumot mér, amennyiben például a remény az élettel való elégedettségnek az optimizmustól és az élet értelmességétől is független prediktora. A reményt konstitutív jellemzők különböztetik meg más pozitív várakozásoktól, úgymint a vágyott cél észlelt elérhe- 
tősége, valamint a célhoz vezető utak elképzelésének képessége (Affleck \& Tennen, 1996). Az optimizmus inkább kapcsolódik a napi rutin történéseihez, míg a remény a jelentős életeseményekhez, szerepe az azok kedvezőbb kimeneteléért való megküzdésben mutatkozik meg (Scioli és mtsai, 1997).

Az optimizmus mint személyiségvonás, Scheier és Carver (1985) meghatározása szerint generalizált elvárás a jó dolgok jövőbeni bekövetkeztére vonatkozóan. Ez az elvárás-jelleg az optimizmus fő megkülönböztető jegye (Snyder és mtsai, 1991; Snyder, 1995). Az optimizmus a pozitív kimenet várása és egyidejúleg a negatív kimenet nem várása. Szondy (2008) meglátása szerint a vonásoptimizmus-modell a személyes hatóerőnek megfeleltethető sikeres célelérésre vonatkozó elvárást hangsúlyozza, a reménymodell pedig kiegészíti ezt az elképzelést a megoldási lehetőségekre vonatkozó elvárásokkal.

Hammelstein és Roth (2002) is a generalizáció mértékében látja a különbséget a reményhez képest. A másik különbség, hogy az optimista számára a jövőbeni kimenetek minősége a fontos, míg a reményteli esetében a vágyott cél bekövetkezte és a saját képességeinek is köszönhető elérése áll a figyelem középpontjában (Bryant \& Cvengros, 2004). Az optimista abban hisz, hogy szerencse révén, mások vagy saját cselekvéseinek köszönhetően megvalósul a sikeres jövő. A reményteliség ellenben sokkal inkább kapcsolatban áll a saját kezdeményezésú aktivitásokkal, amelyek által a személy kivitelezi a sikeres jövendőt. Ő abban hisz, hogy saját képességei révén biztosíthatja azt (Alarcon, Bowling, \& Khazon, 2013). Például Rand és munkatársai (2011) egyetemi hallgatók tanulmányi előmenetelének jobb előjelzőjeként értékelték a reményt, mint az optimizmust. A tudományos teljesítmények elérését befolyásoló remény redukálható akár két jól ismert összetevőre, úgymint tervezés és motiváció, adott konkrét területre vonatkoztatva (Feldman \& Kubota, 2015).

Kimondhatjuk, hogy az optimizmusra nézve inkább a kimenet-jelleg, a reményre nézve pedig egy folyamat-jelleg a meghatározó. Természetesen e folyamat is tart valahová, a vágyott cél felé, és a reménynek mintegy útközben van szerepe. A remény, mint a személynek önmagára vonatkozó hiedelme a célspecifikus elvárások által fejti ki hatását (Rand, 2009).

A két konstruktum eltérően befolyásolja a megküzdési viselkedést. Az optimizmus feltehetóleg a kevésbé kontrollálható stresszorokkal való megbirkózásban segít, előre nem látható akadályok esetén enyhíti a stresszreakciót, tehát adaptívabb emóciófókuszú megküzdést eredményez. Vizsgálatok szerint a derülátó, azaz optimista személyek kevesebb átélt stresszorról számolnak be, és megpróbálják azt pozitívan értékelni, negatív kontextusban pedig hatékonyabban észlelik a helyzet pozitívumait, és jobban figyelnek azokra (Szondy, 2006). Az optimizmus különféle proaktív stratégiákkal mutat kapcsolatot (Scheier, Carver, \& Bridges, 1994), ezen belül is a proak- 
tív megküzdési stílussal (Aspinwall \& Taylor, 1997). A remény sokkal inkább vezet problémafókuszú megküzdéshez (Snyder és mtsai, 1991), ami a célelérést jobban garantálja, továbbá a remény magasabb szintje célirányosabb teljesítményhez segít, és ezen a módon juttatja a személyt nagyobb elégedettséghez (Rand és mtsai, 2011).

Összegzésként Alarcon, Bowling és Khazon (2013) eredményeit emelhetjük ki, amelyek szerint az optimizmus olyan helyzetekben érvényesithetöleginkább, amikor az egyénnek csekély befolyása van a kedvezö kimenetre, a remény pedig akkor jelent erőforrást, amikor bevethetőek a személyes képességek és kompetenciák a jobb jövö érdekében.

\subsubsection{Megküzdés és remény}

Remény híján nem képes az ember segíteni magán. Ahhoz, hogy nehéz helyzetében a változáson tudjon munkálkodni, hinnie kell, hogy az eredményes lehet, hangsúlyozza Lazarus (1999). Szerinte a remény által vezérelve egyidejúleg megvan az esélye az elkerülés-jellegú, de az elérés-orientált megküzdésnek is. Elméleti úton jut el annak felismeréséig, hogy a remény coping-jellege a reménynek mint érzelmi folyamatnak meghatározó eleme. Ugyanakkor a remény a megküzdés facilitátora, és mint pozitív érzelmi állapot, a stresszmenedzsment elősegítóje (Folkman, 1997). „Az önreflektív tudatban, ahol képesek vagyunk figyelemmel kísérni az elsődleges tudatot is magában foglaló lelki folyamatokat, az emberi lény egyfajta »látszatvalóságot « tart fenn, amelyben feltevéseket és terveket kovácsolhat, elébe vágva a környezetben bekövetkező változásoknak. Ez segít kezelni az emberi környezet rendkívül gyors és bonyolult változásait is" - világítja meg Pally (2000, 112. o.). Korner (1970) úgy írja le a reményt, mint az egészséges megküzdés eszközét, amely stresszhelyzetek alkalmával különösen jelentős szereppel bír.

Kutatások sora igazolja immár, hogy a reményteli személyek kihívásnak tekintik a saját maguk által kitúzött életcélokat (Snyder és mtsai, 1991), inkább felismerik az életeseményekkel járó stressszorokkal való megküzdés előnyeit, a súlyos testi betegségek hordozásának pozitív velejáróit (Affleck \& Tennen, 1996; Shorey és mtsai, 2007), jobban megbirkóznak a betegségekkel és különféle fogyatékosságokkal (Elliott, Witty, Herrick, \& Hoffman, 1991; Jackson, Taylor, Palmatier, Elliott, \& Elliott, 1998; Stanton és mtsai, 2000), fájdalomtúrő képességük magasabb (Snyder és mtsai, 2005a), és elégedettebbek az életükkel (Gilman, Dooley, \& Florell, 2006; Valle, Huebner, \& Suldo, 2006).

A remény tehát tartalmaz egy megküzdési viselkedést, olyan, folyamatosan revideált coping stratégiát, amely a külső viselkedésben is megnyilvá- 
nul, és amely a vágyott célhoz eljutásra, a közben eloálló akadályokkal megbirkózásra irányul. Másfelől azonban megküzdési stratégia nincs remény nélkül, amennyiben a reményteliség az a viszonylag tartós, pozitív elvárásokra fókuszált érzelmi állapot, amely mindaddig fennáll, amíg a vágyott cél fontos az egyén számára, vagy amíg el nem éri azt. Ebből az aspektusból a megküzdés legtágabb értelmében vett, érzelmi fókuszú, a negatív érzelmek elnyomását célzó viselkedés esetében is föltételezhetjük a remény motiváló hatását. Talán ennyiben van jelen a remény azon személyek esetében, akik „feszültségcsökkentő" alkohol támogatásával tartják egyensúlyban magukat. Amikor sem a külső tényezők befolyásolása, sem a belső erőforrások mozgósítása nem vezet el a célhoz, tehát amikor a tényleges kontroll birtoklására nincs mód, a represszióval lehet jobban alkalmazkodni a stresszhez (Oláh, 2005). Emellett a megküzdés föltételezi és magában foglalja a remény kognitív faktorát is, amely a vágyott célt az elérhetőség szintjén tartja, miközben fölméri és igénybe veszi a küzdelemhez szükséges ötleteket és erőforrásokat. Lopes és Cunha (2008) optimista illetve pesszimista személyek megküzdési stílusát vizsgálta, reményteliségük függvényében. Vizsgálatukban (n = 343) Snyder és munkatársai (1991) koncepcióját és mérőeszközét (Adult Hope Scales, AHS) alkalmazták, és azt találták, hogy az optimisták proaktív copinggal élnek, függetlenül reménységük mértékétől. Kimutatták továbbá, hogy a proaktív coping a remény mindkét dimenziójával magasan korrelál ( $\mathrm{r}=0.70$ agency; $\mathrm{r}=0.72$ pathways). A pesszimisták esetében viszont szerepet játszik a reményteliség szintje: a reménytelibb pesszimisták kevésbé élnek az egyébként a pesszimistákra jellemző passzív megküzdés formáival.

A megküzdés és a remény eddigiekben ismertetett kölcsönös és dinamikus rész-egész viszonyának köszönhetően a reményteliség a pszichológiai jóllét magasabb fokával (Kwon, 2002; Shorey mtsai, 2007), és a depresszív hangulat alacsonyabb szintjével (Kwon, 2000) jár együtt. A megküzdési magatartás a remény szintjének növelése által közvetve befolyásolható (Lopes \& Cunha, 2008). Pesszimista személyek esetében különösen fontos a reményteliség növelésének lehetősége. Társas támogatással elősegíthető, hogy új célokat találjanak, és kimozdulván a rájuk jellemző passzivitásból, illetve tanult tehetetlenségből, a remény kognitív szintjén új megoldásokat keressenek választott céljaik eléréséhez, illetve a közben keletkező akadályok leküzdéséhez.

A remény-optimizmus-megküzdés viszonyrendszerének összegzéseként kimondható, hogy a reményteli személy inkább képes a környezetéból érkező, derúlátásra okot adó információk felvételére, az optimizmus pedig enyhíti a megküzdéssel járó érzelmi igénybevételt. Az eredményes megküzdésben tehát mindkét személyiségvonás, egymástól elkülöníthető módon szerephez jut, miközben a társas és szituatív tényezők elősegíthetik, 
fölerősíthetik a kettő kölcsönhatásait, növelve az adaptív megküzdés valószínúségét, ezzel a személy önképének pozitív irányba formálódását, és életlehetőségeinek kiteljesítését.

A fentieken túl indokolt néhányat kiemelnünk a megküzdési eredményesség további személyiségfaktorai közül, tekintve, hogy fenyegetések, kihívások közepette, a kár és a veszteség helyzeteiben az a személy képes pozitív egyenleget elérni, akit a remény és az optimizmus mellett olyan protektív vonások is jellemeznek, mint koherenciaérzék, kontrollhit, énhatékonyság-érzés, valamint leleményesség, lelki edzettség, reziliencia (a stratégiák rugalmas alkalmazásának képessége); tehát aki a pszichológiai immunkompetencia eszköztárának köszönhetóen fejlett stressztúrőképességgel rendelkezik (Oláh, 2004).

\subsubsection{Kontrollhit}

Oláh szerint $(2005,77$. o.) „a megküzdő cselekvés valójában az eszköz ahhoz, hogy kontrollt gyakorolhassunk, hogy kontrollképesek legyünk, ugyanakkor minden coping előfeltétele egy bizonyos fokú kontrolláltság, vagy annak megélése." Mint ismert, a külső-belső kontroll attitúd Rotter szociális tanulás elméletében jelent meg elsőként. E személyiségdimenzió, amely az egyén szocializációs tapasztalatainak függvényében alakul, jelentôsen befolyásolja, hogy a személy mit tekint kiszámíthatónak, kezelhetőnek, így tehát a választandó coping stratégiát is. A remény feltehetőleg az elsődleges kiértékelés folyamatában jut szerephez. Egyidejúleg a belső kontroll attitűd a remény egy faktoraként szerepelhet, mint azt Schrank és munkatársai (2008) is feltételezik (ld. fentebb). Azt mondhatjuk, hogy a Csíkszentmihályi (2000) által leírt flow (áramlatélmény vagy optimális élmény) koncepciójából kirajzolódó emberkép valójában a reményteli embert jeleníti meg, aki autonóm módon választott célokat követ és tudatos célválasztásain keresztül képes érzelmi állapotát is kontroll alatt tartani. E koncepció szerint, mint Oláh $(2004,42$. o.) rámutat, „,az emberek nem attól boldogok, amit csinálnak, hanem ahogyan csinálják azt. A flow állapotában az emberek pillanatról pillanatra tudják, hogy mit kell tenniük, vagy mert adott tevékenység úgy kívánja, vagy mert világos célokat követnek, miközben tevékenységüket folyamatos kontroll alatt tartják, és a visszajelentések függvényében alakítják. ... Amennyiben az egyén saját képességeivel elérhető célokat választ, a célelérés útján nagyobb esélyt teremt magának arra, hogy pozitív élmények részesévé váljon."

\subsubsection{Koherenciaérzék}

A pozitív pszichológia egyik előfutára, Antonovsky nevével fémjelezhető salutogenikus megközelítés a stresszt az egészség és fejlődés aspektusából elemzi, fordulatot hozván a megküzdéskutatásban. A stressznek kitett, de 
egészségesként viselkedő személyek vizsgálata ráirányította a figyelmet a stresszel szemben védelmet biztosító személyiségtényezőkre. Az általa definiált koherenciaérzék gyermekkori élmények által formált beállítottság, diszpozíció, amely a személynek a kihívásokkal szembeni válaszképességét jellemzi (Balajti, Vokó, Ádány, \& Kósa, 2007). Egyfajta globális orientáció, komplex önbizalom, annak magabiztos érzése, hogy a dolgok nagy valószínúséggel úgy alakulnak, ahogy az ésszerúen elvárható. Kulcskomponense az értelmes életben való hit (Oláh, 2005). Magában foglalja annak mértékét, hogy az egyén mennyire bízik abban, hogy 1. a külső és belső környezetből származó ingerek bejósolhatóak, strukturáltak és értelmezhetőek (comprehensibility - a kogníció szintjén), 2. elérhetőek azok az erőforrások, amelyek birtokában az eseményekre és történésekre az egyén megfelelő módon reagálni tud (manageability - a magatartás szintjén), valamint, hogy 3. ezen életesemények olyan kihívások, amelyek elköteleződésre és energiabefektetésre érdemesek (meaningfulness - a motiváció szintjén). A fejlett koherenciaérzék a megfelelő copingforrás kiválasztásán és instrumentális alkalmazásán keresztül járul hozzá az eredményes megküzdéshez (Nagy \& Oláh, 2012). Közelebbről annak a stratégiának a kiválasztását irányítja, amely a leghatékonyabb lehet az aktuális fenyegetéssel szembesülve. A kettő kölcsönhatását alátámasztó eredmények (Chimich \& Nekolaichuk, 2004) között figyelemre méltóak Sharabi, Levi és Margalit (2012) kutatásai, amelyek alapján a reményteliség szintje előjelzője a koherenciaérzék mértékének. Nem meglepő továbbá, hogy a remény szintjének növelését célzó tréningprogramok elsősorban a koherenciaérzék azon faktorára hatnak pozitívan, amely az értelmezés és jelentéstulajdonítás képességét foglalja magában (comprehensibility) (Lindén \& Tingbaeck, 2006), alátámasztva azt a hipotézist, miszerint a remény személyes jelentéssel ruházza fel az élettörténeti eseményeket (Schrank, 2008).

\subsubsection{3. Énhatékonyság-érzés}

Az énhatékonyság érzése úgy határozható meg, mint feladatspecifikus önbizalom, a személy szilárd meggyőződése, miszerint képes végrehajtani azokat a viselkedéseket, amelyekkel az általa kitúzött célt megvalósíthatja (Oláh, 2005). Bandura (1977) énhatékonyság elmélete (theory of self-efficacy) jelentős szerepet játszott a remény fogalmának tisztázódásában. Mint Snyder (1995) kiemeli, az elmélet megkülönbözteti a kimeneti elvárásokat, hogy bizonyos viselkedés adott kimenethez vezet, és a hatékonysági elvárásokat, mint a személy azon meggyőződését, hogy képes kivitelezni azt a viselkedést, amely a vágyott kimenetet eredményezheti. Előbbit a megoldási lehetôségek faktorral, utóbbit a személyes hatóerő faktorral állítja párhuzamba. 
Remény és énhatékonyság fejlődéslélektanilag is összekapcsolódó fogalmak. A reményteliség az első életévben alapozódik meg, mint Erik. H. Erikson összegzi pszichoszociális fejlődéselméletében. „A legkorábbi gyermekkor identitáshozama a legrövidebben minden bizonnyal így fogalmazható meg: az vagyok, amiben reménykedem, s amilyen reményt nyújtok" (Erikson, 1991, 455. o.) A szüleihez biztonságosan kötődő csecsemő esetében a bizalom és biztonságérzés talaján kialakuló pozitív érzelmek, mint amilyen a remény is, serkentik a gyermek érdeklődés által vezérelt felfedező tevékenységét, ami által uralmat nyer közvetlen környezete felett. Úgy túnik, a kettő a későbbiekben is kölcsönösen hat egymásra. Nagy és Oláh (2012) eredményei szerint, akik magasabb hatékonyságot feltételeznek önmagukról, azok általában nehezebben elérhetó célokat túznek maguk elé, jobban elköteleződnek azok iránt, és negatív visszajelzés idején is inkább tesznek erőfeszítéseket elérésük érdekében. Remény és énhatékonyság ugyanakkor két, egymástól jól elkülöníthető, önálló konstruktum (Magaletta \& Oliver, 1999). Snyder szerint az énhatékonyság érzése a személy adott szituációkra vonatkozóan becsült önbizalma, a remény azonban ezen túl a szituációktól független személyes hatóerőt is magában foglalja (Snyder, 2002). Hirschi, Abessolo és Froidevaux (2015) pályalélektani kutatásai szerint a diszpozicionális remény mind a pályaválasztás, mind a pályatervezés vonatkozásában befolyással bír, és hatása megkülönböztethetó egyéb változók, így az általános énhatékonyság-érzés jelenlététől. A reményteliség magasabb szintje mellett bejósolható egy eredményesebb pályafejlődés, a kitúzött célhoz vezető utak változatossága és hatékonyabb elérése. Mint Hirschi (2014) megállapítja, a remény és az énhatékonyság érzése egyaránt a jövendőben kitúzött célok elérésére irányul. A kettő azonban abban tér el, hogy a remény magában foglalja mind a személyes hatékonyságra vonatkozó elvárásokat, mind a jövőbeni várakozásokat. Egybefogja a cselekvési szándékot és a cselekvést, tehát az alkalmasnak látszó utak elképzelését és megtervezését is, továbbá erőforrásként jelenik meg a pályafejlődés különböző állomásain.

Összefoglalva: A pozitív pszichológia elméleti keretében a megküzdés nemcsak a nehézségekkel való megbirkózást foglalja magában, hanem a jóllét, a boldogság, az optimális élmény elérését is. Előtérbe kerülnek ezáltal a protektív személyiségtényezők, köztük a remény, amely nem csupán megküzdő viselkedésként, de pozitív érzelemként, valamint a biztonság és bizalom megélésének képességeként is hozzájárul a belső egyensúlyi állapot fenntartásához. A fentiek alátámasztják, hogy a remény szerepe a megküzdésben egyértelmúen eltér egyéb, már bevezetett és vizsgált konstruktumokétól. 


\subsubsection{Megbocsátás és remény}

A reményteliség, mint a jövendőre vagy a személyes fejlődésre irányuló pozitív várakozás (Al Mabuk, Enright, \& Cardis, 1995), egyértelmú együttjárást mutat a helyzeti megbocsátással (Rye és mtsai, 2001). A diszpozicionális megbocsátás és a remény pozitív kapcsolatát ugyancsak több vizsgálat támasztja alá (Hirsch, Webb, \& Jeglic, 2011; Rye és mtsai, 2001). A megbocsátás nyomán csökkenhet a reménytelenség, nőhet a reménység szintje (Al-Mabuk és mtsai, 1995; Freedman \& Enright, 1996; Smedes, 1998; Thoresen, Harris, \& Luskin, 2000). Azon személyek, akiknek megbocsátási hajlandósága magasabb, tudatosan döntenek, túl akarnak lépni a személyes sértettségen, sérelmes helyzeteket követően a bosszúvágyó megoldásokon. Fontos számukra a kapcsolat helyreállítása, és ezzel megadják a lehetőséget egy kielégítőbb, új életstílusra (Kis \& Kovács, 2010). Perspektívájukban benne van a sértő fél is, képesek belátásra és empátiára velük szemben (McCullough, Worthington, \& Rachal, 1997). Adott sérelem megbocsátása ráadásul nemcsak a megbocsátani kész személyt teheti még hosszú idővel a történteket követően is reménytelibbé (Hebl \& Enright, 1993), hanem a megbocsátás gesztusát és jeleit fogadó, a kiengesztelődést megtapasztaló korábbi sértő felet is (Worthington, Wilviet, Pietrini, \& Miller, 2007).

A megbocsátás összefüggésében a remény társas meghatározottsága válik ismét nyilvánvalóvá. Aki reményteli, inkább megbocsájt, aki megbocsájt, reménytelibbé teszi a másikat, a sértő felet. Remény hiján viszont épp ellenkezőleg. Itt jut fontos szerephez a bizalom, amely a remény lényegi aspektusa, különösen, ha kevéssé kontrollálható egy helyzet, ha fölöttébb bizonytalan a végkifejlet, és a pozitív előfeltevésekre nem sok ok van (Tennen, Affleck, \& Tennen, 2002). Toussaint és munkatársai (2008) úgy tapasztalták, hogy a mások iránti megbocsátás mind a reménytelenséggel, mind a depresszióval szignifikáns negatív kapcsolatban áll, miközben a reménytelenség közvetít a depresszió és a megbocsátás között. A reménytelenség más vizsgálatok szerint is közvetlen összefüggésben van a helyzeti megbocsátással. Remény híján a sértett személy kevésbé tud bízni egy sérelmekkel megterhelt kapcsolat hosszú távú rendeződésében, neki konkrét bizonyságokra van szüksége. A reménytelenséggel inkább jellemezhető személyek erősebb jóvátételt igényelnek, a sértő fél részéről érkező jóvátételi lépések pedig esetükben különösen pozitív hatásúak (Kis \& Kovács, 2013). Úgy túnik tehát, aki reménytelibb, kapcsolati sérelmet követően is pozitívabb elvárásokkal képes tekinteni a jövendőre. 


\subsubsection{Vallásosság és remény}

Amennyiben a remény valamely transzcendens célra irányul, annak elérése legtöbbször egy közösségi identitás részét képező eszköztár, rítus, szokásrendszer mozgósítása révén történik. Nowotny (1989) a reményt a spiritualitás egy faktorának tekinti. A spiritualitás tágabb spektrumú lélektani jelenség, mint a hit, vagy a vallásosság. A hit esetében a személyes meggyőződés, a vallásosság vonatkozásában a társas hatások dominálnak, a kettő egymásra hatása, együttjárása a spirituális élet tipikus megnyilvánulása. Farran és munkatársai (1999) szerint hit és remény egymástól elválaszthatatlan, lélektani szempontból csaknem szinonimái egymásnak. A kettő általában pozitív együttjárást mutat. Ha sajátos funkciójuk szerint tekintjük e fogalmakat, akkor a hit nyitja ki a személy perspektíváját a transzcendens dimenzióra, a vallásosság megerősítheti ezt a beállítódást, a remény eközben a célirányos viselkedés és megküzdés facilitátora, és mind ezek egymásra hatása a spiritualitás megélése.

Harold G. Koenig kiterjedt empirikus kutatásaira hivatkozva Moser (2000) megállapítja, hogy a vallásos értelmezések (például, hogy minden jó, amit Isten tesz) és szertartások olyan mértékben táplálják a reményt, amit csak maga az emberi környezet nem képes nyújtani. Ezen értelmezések, mint megoldáskeresési lehetőségek a kontrollálhatatlan vagy megváltoztathatatlan helyzetek elfogadására, a realitáshoz fúződő új viszony kialakítására, reflektált jelenlétre ösztönöznek, adaptív megküzdési módok kialakításához segítenek (Kulcsár, 2009). Követéses vizsgálatok eredményei szerint olyan esetekben, amikor a vallásosságnak negatív hatása mutatkozik, legtöbbször a szenvedés értelmének keresése, esetleg vitatása áll a háttérben. Isten létének megkérdőjelezése, egy büntető istenkép, vagy egyházi személyekkel szembeni negatív attitúd, mint maladaptív megküzdés emellett bizonyítottan nagyobb egészségkockázattal jár együtt (Koenig, Pergament, \& Nielsen, 1998; Pergament, Koenig, Tarakeshwar, \& Hahn, 2004). Ha azonban a hívő ember Istent a remény egyedüli biztos forrásaként éli meg, akkor a kontrollt mintegy áthelyezi Isten kezébe, következésképp hite a legkritikusabb helyzetek és állapotok elviselésére is képessé teheti. Piedmont (1999) modellje szerint az egészséges ember, illetve az egészleges személyiség jellemzőinek egyike, hogy képes felülemelkedni adott helyhez, időhöz kötött nézőpontján, és szélesebb, távlatosabb perspektívából tekinteni helyzetére.

Úgy túnik, a reményre hárul az a döntő szerep, amely meghatározza, hogy a vallásos megküzdési módok előnyös hatást fejtenek-e ki a személy életvitelére, testi-lelki egészségére, szubjektív jóllétére. Mint HassonOhayon, Braun, Galinsky és Baider (2009) kutatása alátámasztja, a remény közvetít a vallásosság és az adaptív megküzdés között. Mellrákkal küzdők női mintáján $(n=233)$ végzett vizsgálatuk szerint a remény szignifikánsan 
hozzájárul, hogy jelentést kapjon számukra a betegségük, és hogy olyan személyes célok felé irányítsák figyelmüket, mint lelki fejlődés, belső növekedés, vagy hozzákapcsolódás egy transzcendens valósághoz. Szerepet játszik abban, hogy jobban meg tudnak birkózni a szenvedés realitásával, és betegségüket inkább képesek integrálni vallásos beállítottságukkal, hitbeli meggyőződésükkel.

\section{3. Összegzés}

A fentieket figyelembe véve kimondhatjuk, hogy a remény konstruktuma önálló magyarázó eróvel bír (Alarcon és mtsai, 2013). Ugyanolyan joggal tekinthetó érzelemnek, diszpozíciónak, állapotnak vagy pszichés erősségnek, mint (emóciófókuszú) kognitív megküzdési stratégiának (Lazarus, 1999; Snyder, 2002). Snyder (2000b; 2002) kimutatja, hogy aki reményteli, pozitívabban gondolkodik, mer mások céljaival azonosulni, nyitottabb közeli kapcsolatokra, és képes tágabb perspektívákat magáévá tenni. Martos és munkatársainak kutatásai (2014) azt igazolják, hogy valóban létezik egy általános remény konstruktum, valamint, hogy a Remény Skála olyan jellemzőt mér, ami nem redukálható az optimizmusra, vagy az élet értelmességének megtapasztalására, és hiánya sem a reménytelenség konstruktumára, illetve nem azonosítható azokkal. Remény és reménytelenség, bár egymástól egyértelmúen megkülönböztethető, mégsem értelmezhető szimplán egyazon dimenzió két végpontjaként (Huen és mtsai, 2015).

A remény alapvetó jellemzője, hogy realitáson alapul (Korner, 1970), a jövendőre irányul, és pozitív előfeltevéseket tartalmaz a vágyott kimenet bekövetkezésére valamint az elkerülendő elkerülhetőségére vonatkozóan, az energiák mozgósítása, célkitúzés és tervezés jellemzi, a cél becsült jelentősége nagy, valamint a kihívás illetve a veszteség eshetőségének, azaz a bizonytalanságnak a kontextusában értelmezendő, tehát gyengén kontrollálható. Személyes hatóerő (agency) komponense nagyjában-egészében megragadja azt a pszichés tényezőt, amelynek révén céljai önvezérelt és hatékony elérésére képes a személy. Ennek köszönhetóen a remény az önbecsülés és önbizalom független prediktora (Halama és Dedová, 2007). A reményteli személy ugyanakkor hatóerejének végességét is tudomásul veszi: tudásának határait alázattal belátja, elfogadja, hogy az ember nem lehet teljes befolyással a társas környezetére, és nem kontrollálhatja a jövendőt (Elliot, 2012). 


\section{A remény klinikai- és egészségpszichológiai vonatkozásai}

\subsection{A remény mint a pozitív lelki egészség összetevője}

Az egészségre nézve kedvező, vagy éppen káros magatartások hátterében álló személyiségtényezők szerepe immár adatokkal támasztható alá, jóllehet a kapcsolat a legtöbb esetben túlmutat egyszerú korrelációs összefüggéseken, amint erre Urbán (2001) felhívja a figyelmet.

A Seligman-féle (2011) pozitív egészségi állapot modellben 1. szubjektív, 2. biológiai és 3. funkcionális tényezők különböztethetőek meg. A remény a szubjektív tényezők között jelenik meg. Peterson és Park (2004) szerint a remény a transzcendenciához kötődő, tehát a tágabb univerzumhoz fúződő kapcsolatot előmozdító, valamint a tapasztalatoknak és életeseményeknek személyes jelentést adó érzelmi erősségek körébe tartozik. Ezen az alrendszeren belül a spiritualitás az, ami irányítja az életvitelt, biztonságérzetet nyújt, amelynek birtokában a személy érti, hol a helye a világban, és koherens hitrendszerrel bír a világ céljával, jelentésével kapcsolatban (Piedmont, 1999), a remény pedig mintegy támogatója a spiritualitásnak (Bagdy, 2014). Olyan személyiségjellemző, amely magában foglalja a jövőbeli pozitív események elvárását és az ezekért való munkát. A remény mint karaktererősség egyfajta belső bizonyosság, hit abban, hogy a jövőbeli jó megvalósulhat. Nem csupán pozitív attitúd és derűs jövendőre irányultság (Seligman, 2008), mégpedig a jövendőtől a legjobbat várva, de egyúttal motiváció is, amely arra ösztönzi személyt, hogy e kedvező kimenet eléréséért mindent megtegyen.

Az erősségeknek, mint pszichológiai konstruktumoknak legfontosabb kritériuma az univerzalitás, a világ szinte valamennyi kultúrája általi elfogadottság. További jellemzőit Oláh (2004) így foglalja össze: vonás jellegú, sokfajta helyzetben jelenik meg és időbeli stabilitást mutat; az a jellemző, amelyet a szülők kívánnak az újszülötteiknek; az erősséget önmagáért értékeljük, és a cselekvés, amelyre késztet, önmagában jutalmazó jellegú; gyakorlása emelkedettséget, pozitív élményállapotot eredményez, és másokat is követésre sarkall; a kultúrák szerepmodelleken, példabeszédeken és alapvetően a gyermekmeséken keresztül fejlesztik az erősségeket. Kedvezó esetben a társadalom által létrehozott intézmények és rituálék táplálják az erősségek kifejlődését és fennmaradását (Erikson, 1968), sőt azok elismert példaképek által is megjelenítődnek.

A karaktererősségek azon ismertetőjegyei, amelyek használatuk közben megnyilvánulnak, a következők (Seligman, 2011): a hitelesség érzése, izgalomérzés, gyors tanulási görbe a gyakorlása során, vágy az új módokon való alkalmazásra, az elkerülhetetlenségének érzése, teljes megerősödés, olyan személyes célok és tervek alkotása, amelyek adott erősségre építenek, 
továbbá öröm, élvezet és lelkesedés az erősség használatakor. Ugyanez várható tehát, amennyiben a személy a reményt azonosítja erősségeként. Szondy összegzése szerint (2011) az erősségek egydimenziósak, nem bonthatóak tovább. Egyaránt megnyilvánulnak a gondolkodás, érzések, cselekedetek terén, hozzájárulva a „jó élet” beteljesüléséhez. Általában kívánatos kimenetekhez vezetnek, megnyilvánulásaik csodálatot és elismerést keltenek. Valamennyi erősség saját jogán morálisan értékes, még pozitív kimenetek hiányában is.

A pozitív pszichológia megközelítése szerint (Oláh, 2004) egészségesen és hatékonyan múködik az a személy, aki képes arra, hogy többnyire az erősségeit használva feleljen meg az alkalmazkodási követelményeknek. Míg Miller (1989) még arra keresett választ, hogy kritikus életesemények közepette milyen intervenciók fokozhatják a remény szintjét, Snyder és munkatársainak (1997b) eredményei már rávilágítottak a diszpozicionális remény nevelés, illetve terápiás kapcsolat által fejleszthető voltára. A pozitív pszichoterápiának pedig kifejezett célja, hogy elősegítse a karaktererősségek felvállalását (Proyer, Ruch, \& Buschor, 2013; Seligman, 2011; Szondy 2011). Seligman (2011) eredményei igazolják, hogy amennyiben az egyén felismeri és felvállalja karaktererősségeit, és törekszik alkalmazásukra a mindennapokban, megtapasztalhatja azok sajátosságait, sőt, azoknak köszönhetően súlyos depressziósok esetében a korábban mért depresszió súlyossága szignifikánsan enyhül.

Olyan védőfaktorként tekinthetünk tehát a reményre, mint ami a serdülő ifjakat ellenállóbbá teszi a rájuk következó életeseményekkel szemben (Valle és mtsai, 2006), és amelynek mért szintje az újabb kutatások eredményei szerint előrejelző tényezőnek bizonyul a depresszió, szorongás és az öngyilkosság esetében (Arnau, Rosen, Finch, Rhudy, \& Fortunato, 2007; Davidson, Wingate, Rasmussen, \& Slish, 2009).

\subsection{A remény mint adaptív magatartás}

A reményteli személy a magaválasztotta és értékesnek ítélt cél elérésére törekszik, ezáltal az önaktualizáció élményét és egy teljességre irányuló életstílust élhet meg. A választás szabadsága, azaz az öndetermináció növeli a kontroll érzését, és a szubjektív jóllétet (Deci \& Ryan, 2004; Schwartz, 2000). A szabadság megtapasztalásával együttjáró bizonytalanságérzést ellensúlyozzák a választott és a döntéseket megalapozó értékek. Amennyiben a személy érzelmi reakciói és tudatos döntései egyaránt azt jelzik vissza a számára, hogy értékes az élete, elégedettebb lehet a sorsával (Diener, Lucas, \& Oishi, 2005). 
A növekedésre kész egyén bátrabban néz szembe a környezetéből érkező kihívásokkal, és örömmel mozgósítja képességeit azok legyőzése érdekében. Kutatások sora támasztja alá, hogy a reményteliség mértéke pozitív együttjárást mutat a magasabb iskolázottsággal, magabiztossággal, a tudatosabb egészségmagatartással (Horton \& Wallander, 2001), sőt, a jobb sportteljesítménnyel (Curry, Snyder, Cook, Ruby, \& Rehm, 1997). Snyder és munkatársai (1997b) egy éven át követték nyomon a reménység stabilitását, prediktív validitását, valamint a reménység közvetítő szerepét a fiatalok eredményessége és szubjektív jólléte viszonylatában. Prospektív vizsgálataik szerint iskoláskorúaknál a remény magasabb foka jobb társas kapcsolatokkal, magasabb önbizalommal, optimizmussal és jobb továbbtanulási esélyekkel társul. Shorey és munkatársai (2007) több kutatás egybevetése alapján azt mondják ki, hogy a reményteliek számára csaknem természetes a magas szintú egyéni vagy csoportteljesítmény, mivel teljesen világosan meghatározott célokat képesek kitúzni, a célhoz vezetó utaknak különféle variációit tudják kidolgozni, bekalkulálva az esetleges tévedéseket is. Teljesítményszorongásuk kisebb mértékú, sikertelenségeket követően is jobban megőrzik jó hangulatukat, ami szükséges ahhoz, hogy kitartóak legyenek és hatékonynak éljék meg magukat. Ong, Edwards és Bergemann (2006) a késői felnőttkor alkalmazkodási folyamatában igazolta a remény erőforrás funkcióját. A szerzők 226, véletlenszerúen kiválasztott idősödő személlyel lefolytatott, 45 napon át tartó vizsgálatuk során úgy találták, hogy stresszteli életesemények közepette az állapotreménység kevesebb negatív érzelemmel és jobb megküzdéssel járt együtt. A helyzetfüggő remény személyen belüli hatásaként mutatták ki továbbá a kisebb mértékú stresszreaktivitást, közvetett hatásként a gyorsabb felépülést a stresszel teli helyzetek után. Úgy találták, hogy a diszpozicionális remény előre jelzi az adott helyzetben megjelenő remény mértékét. Magasabb vonásreménység-értékek mellett eredményesebb érzelmi megküzdést és csekélyebb stresszreaktivitást mutattak a személyek. Személyközi szinten a reménytelenséggel inkább jellemezhetô személyek magasabb napi stressz-szintről számoltak be, míg az általában reménytelibbek napi reménység szintje a negatív érzelmek megfékeződésében mutatkozott meg. E dinamikus kölcsönhatás tehát úgy érvényesül, hogy a reménytelibbek konkrét helyzetekben eredményesebben alkalmazkodnak a nehézségekhez (Snyder, 2002; Fleeson, 2004).

Forstmeier, Uhlendorff és Maercker (2005), a diagnosztika új ismérveiként tekint a pszichés erősségekre, mint a DSM-rendszer szerinti negyedik tengelyen elhelyezhető személyes és társas erőforrásokra, amelyek mind az egészségnek, mind a lelki zavarok gyógyításának befolyásoló tényezői. Megállapítják, hogy a remény szintjének növelését célzó, egyéb terápiás beavatkozásokkal kombinált csoportos intervenciókkal sokkal jobb eredmény 
érhető el idős depresszív személyeknél, és mint motiváció jellegú erőforrást kategorizálják a reményt. A külső ágensekre (external locus-of-hope) irányuló intervenciók hatékonysága vegyes mintán is igazolást nyert. Családtagok, vagy a jelentős másik személy reményteliségének növelése az érintett személyes hatóerejének és célelérő képességének támogatását szolgálja (Du, Bernardo, \& Yeung, 2015).

A mentális betegségekből felépülés egyik legbiztosabb mutatója, amikor a múltbéli életesemények és tapasztalatok új, a jelen helyzetekre kiható, a mindennapi életet elősegító jelentést nyernek. A reményteliség feltehetóleg újszerú adaptációs mintázatok meghatározója; alakítja a szituációk értelmezését, formálja a jelentéstulajdonítást, ezáltal megfelelőbb alkalmazkodást tesz lehetóvé a kihívásként jelentkező élethelyzetek során.

\subsection{A reménytelenség mint kockázati tényező}

A remény és az egészség közötti, immár többszörösen igazolt, de robosztus összefüggés még sok vizsgálható részletet rejt. Már Erickson és munkatársai (1975) megállapították, hogy amennyiben a személy jellemzően alacsonyra becsüli a számára vágyott célok elérésének valószínúségét, pszichopatológiai szempontból veszélyeztetettebb. Amennyiben a célelérés eredményességét kevéssé valószínúsíti, ám a vágyott cél nagy jelentőséggel bír a számára, fokozott mértékú szorongást él át.

Amikor a szenvedő ember számára a jövőperspektíva lezárul, reménytelennek látja a helyzetét. A reménytelenség fokozott egészségi kockázatot jelent mind az önkárosító magatartásformák, mind az élettani kihatások okán. A remény elvesztése nagyban gátolja a segítségkérést, vagy annak elfogadását. Szívinfarktust, illetve szívmútétet követően tényleges kockázati tényező a reménytelen lelkiállapot (Kopp, 1997a; Tordai, 2006). Ekkor egészen konkrét és speciális lelki támogatásra van szükség. A hatékony terápia növelni képes a célelérés sikerességének szubjektív valószínúségét.

Abramson, Metalsky és Alloy (1989), akik még elméleti alapon különítik el a reménytelenség folytán kialakuló depresszív tünetegyüttest, az oksági láncolat időbeli tagoltságára mutatnak rá, a negatív életesemények értelmezése folytán kialakuló reménytelenség és a klinikai tünetek megjelenése közötti jelentős időbeli eltolódásra irányítva a figyelmet. A tanult tehetetlenség újraértelmezett elvére (Abramson, Seligman, \& Teasdale, 1978) épülő modelljükben a stresszel teli életesemények sokasága akkor vezet reménytelenséghez, ha oksági attribúciói folytán a személy kontrollálhatatlannak, befolyásolhatatlannak, megváltoztathatatlannak tekinti a történteket, ezért tehetetlennek érzi magát, és passzívvá válik. Kopp (1997a) e modellt felhasználva fejti ki, hogy amennyiben egy érzelmileg negatív helyzetben tar- 
tósan fennmarad a kontrollvesztés érzése, akkor a szorongás átadja helyét a tanult tehetetlenségnek, majd a reménytelenségnek és a depresszív állapotnak. Például a társadalmat megosztó gazdasági különbségek is a reménytelenség érzése és a depresszió közvetítésével vezetnek magasabb megbetegedési arányhoz (Kopp, 1997b). Susánszky, Szántó és Körmendi (2013) azt mutatja ki a magyar lakosság körében végzett reprezentatív, Hungarostudy elnevezésú kutatás adatai alapján, hogy nem a tényleges relatív jövedelmi egyenlőtlenség a közvetett egészségi kockázati tényező, hanem a jövedelmi helyzet percepciója. A szubjektíve észlelt vagy a viszonylagos lemaradás, majd a reménytelennek ítélt életkörülmények a depressziós lelkiállapot kialakulásával és a társuló metabolikus szindrómával önsorsrontó körré zárulhatnak.

Beck, Weissman, Lester és Trexler (1974) szerint a reménytelenség negatív elvárások rendszere a saját jövendőre vonatkozóan, a világgal és önmagával kapcsolatosan, valamint a másik ember irányában (Tringer, 2005). E rigid kognitív sémákból álló mentális szưrő a személy felé irányuló információkat negatív attitúdök mentén kezeli, azaz csak azt engedi bejutni a tudatba, ami megfelel az egyén előzetes vélelmeinek. A reménytelenség számos pszichopatológiai kórkép összetevője, a depresszió tipikus velejárója (Lazarus, 1999).

Esteves, Scoloveno, Mahat, Yarcheski és Scoloveno (2013) harminchat, 1990-2010 között született publikációt tekintett át, amelyek rámutattak a stressz, a szorongás, valamint a depresszió és a remény összefüggései további kutatásának fontosságára. Megfontolásra érdemes például azon vizsgálati eredmények sora, amelyek szerint szuicídum esetében nem a depreszszió súlyossága a kórjelző tényező, hanem a reménytelenség mértéke. Perczel Forintos, Sallai és Rózsa (2001) a Beck-féle Reménytelenség Skála validitásvizsgálata során visszaellenőrizte a reménytelenség relevanciáját szuicid veszélyállapotokban. Úgy találták, hogy a depressziósok szélsőségesen negatív jövőképpel rendelkeznek, ugyanakkor az öngyilkossági szándék sokkal erősebben korrelál a negatív elvárásokkal, mint magával a depresszióval. Perczel Forintos és munkatársai (2001) a reménytelenség specifikumát egyetlen faktorba rendezhetónek tekintik, amelyet a "Sötéten látom a jövőmet" megfogalmazás fejez ki. A reménytelenség magas foka mellett kevésbé várták el a kontrollszemélyek, hogy mások viszonozzák jócselekedeteiket. Kutatásaik alapján a reménytelenség önálló konstruktum jellege is visszaigazolást nyert, amikor az nem mutatott szoros kapcsolatot a Diszfunkcionális Attitúd Skála (DAS) egyetlen alskálájával sem. Martos és munkatársai (2014) ugyancsak kimutatták, hogy a Remény Skála különbözik a Beck-féle Reménytelenség Skálától (BHS), mivel utóbbiban a tételek jelentős része a jövővel kapcsolatos elképzelések és várakozások általános negativitását fogalmazza meg, a Snyder-féle koncepció viszont nem általános pozitív vára- 
kozásokra utal, hanem a célok önvezérelt és hatékony elérésének lehetőségére. Tehát a két skála által mért jellemző nem tisztán egymás ellentétpárja, bár természetesen nem is függetlenek egymástól.

A reménység realitásalapú, míg a reménytelenség a negatív kognitív szúrést követően eloállt értelmezéseknek köszönhetően bontakozik ki. E ponton újra hangsúlyossá válik a fogalmi distinkciók cikkünk elején megfogalmazott igénye: adott esetben a kérdés, hogy szuicidprevenció szempontjából a remény alacsony szintje megfeleltethetó-e a reménytelenség konstruktumának, tekintve, hogy a negatív elvárások magas szintje nem feltétlenül ekvivalens a pozitív elvárások alacsony szintjével. Már Macleod, Rose és Williams (1993) rámutat, hogy a kvalitatív eltérés mellett a faktoriális vizsgálat a döntő a tekintetben, hogy a szuicid szándék a reménytelenség-szülte, a jövendőre vonatkozó negatív elvárásokkal, vagy a reményteliség alacsony szintjének megfelelő pozitív elvárások hiányával áll-e összefüggésben. Huen és munkatársai (2015) mind elméleti, mind empirikus alapon azt állítják, hogy a nagyfokú reménytelenség hordozza magában az öngyilkossági fantáziák kialakulásának kockázatát. A reménytelenség növeli a negatív érzelmek megjelenésének gyakoriságát, fokozza a maladaptív megküzdési stratégiák megjelenését, majd az eredménytelen megoldási kísérletek kulminálnak a szuicid tervekben és képzetekben. Eközben a remény szintje nemcsak hogy előrejelző tényezőnek bizonyul a depresszió, szorongás és az öngyilkosság esetében (Arnau és mtsai, 2007; Davidson és mtsai, 2009), hanem mint Huen és mtsai (2015) rámutatnak, a remény közvetít a reménytelenség és a szuicid fantáziák között. A reményteliség magasabb szintje enyhíti a reménytelenség negatív kockázati hatását, gátolja a szuicid gondolatok kifejlődését. A remény erősítése tehát preventív faktor az öngyilkosság megelőzésében.

Depresszív hangulati zavarok idején állandósul a kilátástalanság és a fenyegetően bizonytalan jövő elővételezése. A depresszió tüneti képe szoros összefüggést mutat bizonyos demográfiai változókkal, mint a nem, vagy az életkor. Kopp, Skrabski és Czakó (1990) 21 ezres reprezentatív magyar mintán végzett vizsgálata szerint a 39 év alattiak $8 \%$-a, a $40-49$ évesek $11 \%$-a, az 50-59 évesek 16\%-a, a 60 év felettieknek pedig 25\%-a látja jövőjét reménytelennek. Miközben az adatok mind a családi állapot változásával, mind a munkaképesség csökkenésével, mind egyéb, akár helyi szocio-ökonómiai tényezőkkel összefüggenek. Rámutatnak arra a tendenciára is, miszerint az öregkor értékes volta nem kap hangsúlyt a társadalmi tudatban, valamint, hogy az életcélok kitúzése és elérhetőségének becslése elsősorban külső tényezők függvényeként jelenik meg, és nem a személy vagy a társas közeg belső erőforrásainak összefüggésében. A reményvesztettség az unipoláris depresszió, mint 2020-ra világviszonylatban feltehetőleg a második legnagyobb gyakorisággal előforduló betegség (Lopez, Mathers, Ezzati, Jamison, 
\& Murray, 2006) egyik fő okaként kezelendő. Ennélfogva a gyógyító-segítő szakemberek feladata nemcsak a depressziós személy alultmotiváltságának, a „rajtam úgysem lehet segíteni” lelkiállapotának ellensúlyozása (Hajnal, Tóth, Székely, \& Purebl, 2013), hanem az egészségügyi rendszerben dolgozók érzékenységének növelése is.

\subsection{A remény mint terápiás tényező}

Gottschalk (1985) a korai életesemények és a késóbbiekben kialakuló szomatikus vagy mentális megbetegedések közötti összefüggés vonatkozásában kulcstényezónek tekinti a reményt. Preventív funkciót tulajdonítva a reménynek föltételezi, hogy a reményteli személy vulnerabilitása kisebb mértékú, a megbetegedések bekövetkezte kevésbé valószínú. Szakirodalmi adatok alapján a remény preventív, promotív és kompenzatórikus szerepet tölt be csakúgy a szomatikus, mint a pszichoterápiás beavatkozások során. Hazai tapasztalatok nyomán ugyanakkor úgy túnik, hogy a pszichoterápia mint alkalmazott tudományág könnyebben befogadja a spirituális dimenziót, mint az orvoslásról alkotott elméleti modellek (Bodor, Andrejkovics \& Frecska, 2015; Andrejkovics, Gasparik, Bokor \& Frecska, 2013). A beteg lelki problémáira irányuló, hosszabb folyamatot felölelő segítő kapcsolat megteremti annak keretét, hogy az emberi létnek több aspektusa szóba kerüljön (lásd például Buda \& Kopp 2001; Kulcsár, 1998; Tomcsányi, 2000; Tomcsányi, CsákyPallavicini, Ittzés, Semsey \& Török, 2006). Az elérendő cél, amelyre a remény irányul, szükségszerúen az aktuális élethelyzeten kívül helyezkedik el.

A remény közvetít az egészség főbb dimenziói és kimeneti faktorai között (Schrank és mtsai, 2011). Pozitívan korrelál a mentális egészség két fontos összetevőjével, úgymint az élettel való elégedettséggel, valamint az önbecsüléssel (Halama \& Dedová, 2007). Általában hatékony előjelzője a gyógyulás valószínúségének, ezáltal a jobb életminőség garanciája. Nem tekinthető túlzónak Beate Schrank megállapítása (Schrank, Bird, Rudnick, \& Slade, 2012), aki szerint a remény központi jelentőségú terápiás tényező, a gyógyulás eredményességének garanciája. Pszichiátriai betegek körében végzett kutatásai és széleskörú szakirodalmi áttekintés alapján fogalmazza meg kijelentését (Schrank és mtsai, 2012; Schrank és mtsai, 2008), amely szerint a beteg számára a remény adja meg azt a kezdeti bátorságot, amely szükséges a saját fejlődésének és javulásának útján elinduláshoz, azaz, hogy tegyen is a maga gyógyulása érdekében, valamint a további motiváció fenntartásához. Szerepe van abban is, hogy krónikus betegséggel együtt élők képesek legyenek szenvedésük, betegségük, fájdalmaik előnyös velejáróit felismerni.

A személyes célok optimalizálása, a saját és a társas erőforrások azonosítása és mozgósítása különösen jelentős az idősek pszichoterápiájában, a vá- 
gyott célok eléréséhez korábban meglévő készségek és képességek elvesztését követően (Forstmeier és mtsai, 2005). Az intrinzik életcélok elótérbe állítása kimutathatóan védőfaktornak tekinthető a lelki egészség szempontjából (Martos, 2013). A célok, mint az emberi személyiség és magatartás vezérlői, segítik a személy szubjektív élményeinek megértését. Mind az életút szerveződése, mind a társas kapcsolatok leírása, összességében a teljes élet minősége szempontjából kulcsszerepük van.

A gyógyithatatlan betegséggel élők jelentik azt a következő célcsoportot, ahol a remény szerepe jól vizsgálható. A bármikor bekövetkező halál bizonytalansága és az életben maradás reménye közötti vívódás egy olyan elhúzódó krízisállapot, amikor a remény sajátos célokra irányul, és a társas támogatás egyedi formái válnak fontossá. Recidív stádiumban a tünetek kontrollja és a fájdalomcsillapítás könnyítheti meg a remény megfelelő tárgyainak felismerését, a békés halálra készülést (Schuth, 2006). FrankeLompa (2006) beszámolója szerint a végső stádiumban lévő tumorbetegek szokásos kérdése mögött, „,Doktornő, meddig fogok élni?”, az a kérés húzódik meg, hogy „Hagyj még reménykedni!” A gyógyító-segítő személyzet úgy segitheti elő a remény fennmaradását, ha eléri, hogy a beteg lehetőleg ne maradjon egyedül a betegséggel, és amennyiben lehetséges, megtalálják számára, és meg is kapja a megfelelő kezelést. A betegség előrehaladtával egyre szúkülő életterek is értelmet nyerhetnek, ha van elfogadó környezet, akik szemében az ember méltósága nem a teljesítményétől, munkaképességétől, szépségétől, épségétől függ, hanem önmagábanvaló. Üres szavak helyett tényleges vigaszt nyújthat a szenvedő mellett álló, és mellette állását szavak nélkül kifejezésre juttató nóvér, orvos, pszichológus, lelkész, családgondozó. A kórházi-klinikai team bármely tagja nyújthat támogatást a beteg autonómiaérzésének fenntartásához, amelyben jelentős szerep jut a mindenkori helyzethez képest reális cél kitúzésének és az elérésében való reménynek.

A pszichodramatikus Frede (2006) szerint a gyógyithatatlan betegek reményének tárgya az önrendelkezés és az elismerés. A pszichodráma mint terápiás módszer elősegítheti a remény fennmaradását, megszilárdulását, elsősorban a spontaneitás, a kreativitás és az aktív cselekvés gyakorlása által. A csoportjáték elemi eszközeként alkalmazott szerepcsere a saját szereprepertoáron belüli új viselkedések kipróbálására ad lehetőséget, bővítve a célok kitúzésének és a változatos megoldások megtalálásának esélyeit. A pszichoterápiás eszköztár hozzájárul ahhoz, hogy egy terminális időszakban járó páciens is, beszúkült élettere és életfeltételei mellett, illetve ellenére megőrizze belső szabadságát. Betegségével szemben bizonyos belső távolságot alakíthasson ki, helyzetére a maga szempontjából kielégítő válaszokat 
találjon, és halálát a saját halálaként élhesse meg, mint élete utolsó célkitúzését. Esetükben a remény a még megváltoztathatók megváltoztatásának, valamint a megváltoztathatatlan igenlésének bátorságában nyilvánul meg. Amikor a gyógyító személyzet sem tehet már semmit a gyógyulásért, akkor puszta jelenléte és a beteg mellett állása jelzi, hogy a remény az élet legvégéig lételeme az embernek (Yalom, 2000).

Koehn, O’Neil és Sherry (2012) kutatásai igazolják a remény régóta ismert kulcsszerepét a szerhasználókkal folytatott eredményes terápiában, illetve konzultációban. A segítő a reményteliség megjelenítője, aki maga a remény bőséges forrásaival bír, és bízik a változásban. Közösen építik fel a kliens reménységét, amelyben a pozitív érzelmi állapot fenntartása és a megküzdés kognitív összetevői egyidejúleg hangsúlyosak. E folyamat többlépéses intervenciókkal segíthető. A kezdő fázis a teherbíró terápiás kapcsolat kiépítése, a középső szakaszban a kliens személyiségének fejlesztése, valamint interperszonális és transzperszonális kötődéseinek helyreállítása, továbbá a jövendőbeli változás esélye kerül előtérbe, az utolsó szakaszban pedig a lehetséges utak megtalálása és „,a következő lépés” kidolgozása történik.

A remény többszörösen igazolt közvetító szerepe a hozzátartozói csoportok múködése során is tetten érhető (Horton \& Wallander, 2001). Azon felnőttek esetében, akiknek tartósan beteg családtagról kell gondoskodniuk, a remény magasabb foka mellett alacsonyabb mértékú distressz mutatkozik. Hasonlóképp táplálja a reményt a nyílt kommunikáció kialakítása és fenntartása a hozzátartozókkal és barátokkal, akik egy bizalommal teli közegben könnyebben fogalmazzák meg kétségeiket és kérdéseiket. Ha a hozzátartozót kevésbé terheli meg a betegápolás, a beteg is jobban viseli a szenvedést, mivel a betegségből fakadó objektív stressztényezők súlya és jelentése a gondozó személy gondolkodásának és érzékelésének szürőjén át fejti ki érzelmileg befolyásoló hatását.

Jövővel kapcsolatos elvárásaink minden bizonnyal kapcsolatban állnak legfontosabb egészségmutatóinkkal, állapítja meg Szondy (2006). A remény a potenciálisan negatív jövendő láttán is segít fókuszban tartani a személyes döntések jelentőségét és esélyeit (Langer, 2005). Ezen a szinten a veszteségek is a célirányos gondolkodás személyes tapasztalatokba épült inherens elemei, a reményteliség másodlagosan megjelenő motivátorai (Snyder, 1996). A személyiségvonások és az egészségi állapot összefüggéseit vizsgáló, az erőforrásokat és kompetenciákat szem előtt tartó pozitív pszichológiai szemléletmód tehát hatékonyan egészítheti ki a pszichopatológiai megközelítést és a klinikai diagnosztikát. A remény egészségerősítő szerepének tudatosítása kiváló példát szolgáltat e területek egymásra utalt voltának elfogadására. 


\section{A remény mérése}

A mérőeszközök fejlesztése egyidejúleg zajlott a konceptuális megértésre törekvéssel (Beck és mtsai, 1974). Mint arról Lipps és Huppmann (2006b) beszámol, a reménység-skálák többsége a szociális gondozás területén került kialakításra. Farran és munkatársainak (1999) összefoglaló munkája áttekintést ad az addig alkalmazott mérési eljárásokról. Figyelemre érdemes, hogy az alábbiakban bemutatandó skálák egyre komplexebbek, a mögöttük álló mind differenciáltabb elméleti háttér függvényében.

A legkorábbi egydimenziós megközelítések Stotland (1969) koncepcióját veszik alapul (Erickson és mtsai, 1975; Gottschalk, 1974; Snyder és mtsai, 1991; Snyder, 1996; Stoner, 1982; Staats, 1989), aki pszichiátriai betegek körében végzett kutatásai nyomán úgy írja le a reményt, mint bizonyos cselekvések motivációs hátterét, amely szükséges, bár nem elégséges feltétele az eredményes terápiának. A reményt szerinte két tényező határozza meg: egy bizonyos cél jelentősége, valamint az elérés valószínúségének érzékelése. Erickson és munkatársai (1975) Hope Scale (EHS) skálája az első, amely a válaszadó önbevallásán alapul. A remény kognitív összetevőire kérdez rá, a válaszadó a konkrétan megnevezett célok személyes fontosságára, továbbá az elérés valószínúségére nézve tesz becsléseket.

Dufault és Martocchio (1985) modellje, amely ugyancsak többek számára szolgált elméleti alapul, a remény hat dimenzióját nevezi meg, amelyek kognitív-temporális (pl. „Látom a fényt az alagút végén.”), affektív-viselkedéses (pl. „Hitem vígaszt nyújt számomra.”), illetve affiliatív-kontextuális (pl. „Képes vagyok szeretetet/gondoskodást adni és elfogadni.") párosításban jelennek meg. E modellre épül a Miller és Powers (1988) által kifejlesztett Miller Hope Scale (MHS), megragadva a reménység három, általuk kimutatott, s az előbbivel harmonizáló összetevőjét, mint 1 . a jövendő elővételezése, 2. a reményt veszélyeztetó tényezók kerülése, valamint 3. az önmagával, a másikkal és az élettel való elégedettség. Herth (1992) az addigi kognitív felfogást multidimenzionális megközelítésekkel gazdagítja, amikor a reménységet személyes, dinamikus életeróként értelmezi, mint ami a vágyott és reális, de bizonytalan cél elérésére irányul. Skálája a Herth Hope Index (HHI), amely krónikus betegek aktuális reménységének fokát méri, széles körben használatos (Farran és mtsai, 1999; Gestel-Timmermans és mtsai, 2010), a korábbi fejlesztésú mérőeszköz (Herth, 1991), a Herth Hope Scale (HHS) rövidített változata. Varimax rotációval végzett faktorelemzés útján 1. az időbeliség-jövőre irányulás, 2. a pozitív készenlét és elvárások, és 3. a dolgok összefüggésének faktorát különítette el. Nowotny (1989) 29 itemes méróeszköze (Nowotny Hope Scale) a remény hat, általa fontosnak tartott jellemzőjét fogja át: 1. jövőorientált, 2 . magában foglalja az egyén aktív részvételét, 3 . a személy bensőjé- 
ból ered és kapcsolatban áll a bizakodással, 4. a remélt dolog egyben lehetséges is, 5 . más emberekre vagy egy magasabb rendú lényre irányul, valamint 6. végeredménye jelentőséggel bír az egyén számára.

Snyder és munkatársai fentebb bemutatott koncepciója alapján több skála is kidolgozásra került. A személyt általában jellemző (diszpozicionális) reményt nyolc állítás mentén ragadja meg a Hope Scale (Adult Hope Scale, AHS; Snyder és mtsai, 1991). Négy item a személyes közremúködés becsült hatékonyságának (agency) mérését célozza, amikor is a múltban és a jelenben megtapasztalt, illetve a jövendőben várható sikeres célelérésre kérdez rá, a másik négy item a célhoz vezetó utak felfedezésének kognitív képességét (pathways thinking) méri, ezen felül négy, ún. töltelék-tétellel egészül ki a tizenkét tételes skála. Martos és munkatársai (2014) a Remény Skála magyar adaptációjának (AHS-H) elkészítésekor vizsgálták a skála faktorszerkezetét, megbízhatósági mutatóit és validitását. A két alskálát a Személyes hatóerö, illetve a Megoldási lehetőségek elnevezéssel indították útjára. Konfirmatív faktorelemzésük megerősíti egy általános reménykonstruktum létezését, továbbá alátámasztja, hogy a két alskála jelentős részben egy közös konstruktum kifejeződése. Megállapítják, hogy a mérőeszköz éppúgy jól alkalmazható a remény általános szintjének, mint összetevóinek mérésére. Snyder és munkatársai kifejlesztettek egy, a remény tartalmára, elvárás-jellegére irányuló, tehát állapotreménység skálát (Adult State Hope Scale, ASHS, Snyder, 1996) is, valamint egy, a 8-16 éves gyermekek vizsgálatára alkalmas kérdóívet (Children's Hope Scale), amely utóbbi a két faktort mindössze hat itemben ragadja meg (Snyder és mtsai, 1997b).

A Schrank és munkatársai (2011) által összeállított Integrative Hope Scale (IHS) a remény azon integratív koncepciójára épít, amelyben az idő, cél, kontroll, társas viszonylatok és személyes jellemzők egyaránt szerepet játszanak. Három korábbi, ezúttal is bemutatott skálát használtak fel (Miller Hope Scale, Herth Hope Index, Snyder Hope Scale), és ausztriai vegyes mintán tesztelték $(n=489)$. A kérdőív mindössze 23 itemet tartalmaz és négy dimenziót fog át, úgymint 1 . bizalom és bizonyosság, 2. pozitív jövendőre irányultság, 3. társas kapcsolatok és személyes értékek, 4. a perspektívák hiánya.

Nem kétséges tehát, hogy a remény mérésére többdimenziós skálák alkalmasak, amelyek az egyes összetevőkre kérdeznek rá, klinikai használat céljából leginkább a terápiás intervenciók érdekében, amelyek eredményességéhez a remény pontosabb mérhetősége nagyban hozzájárulhat (Hellman, Pittman, \& Munoz, 2013). Számolnunk kell azonban azzal, hogy a remény tárgya nagyban eltér a krónikus betegek, illetve az átlagpopuláció esetében. Hasonlóképp kultúr-, illetve rétegspecifikus különbségeket feltételezhetünk az egyes országok, társadalmi csoportok reménységének tartalmában 
(Averill, Catlin, \& Cohn, 1990; Farran és mtsai, 1999). Kimutatható összefüggést találunk a szubjektív anyagi helyzettel is (Martos és mtsai, 2014), továbbá életkori eltéréseket is, miszerint a gyermekek és serdülők olykor egészen egyéni módon fogják fel a célokat és az azok útjában álló akadályokat (Valle \& Suldo, 2004), illetve az idősebbek inkább az életfontosságú célokra irányítják váradalmaikat, mintegy jobban érzékelve az emberi élet határait, mint a fiatalabbak (Seemann, 2006).

\section{Gyakorlati implikációk}

A remény mint lélektani jelenség szociálpszichológiai és egészségtudományi jelentőséggel bír. Kulcsszerepet játszik a munkaegészség megőrzése és fejlesztése tekintetében, az önmenedzsment, a karrierépítés, a hivatásgondozás során (Hirschi és mtsai, 2015). A személyes kompetenciáival jól gazdálkodó, akadályok közepette is pozitív mérleget vonó és céltudatosan előretekintő reményteli ember a huszonegyedik század életképes ideálja.

A remény pozitív erkölcsi értékekkel kapcsolatban álló lelki múködés, és mint ilyen kihatással van a munkateljesítményre és a feladat iránti elkötelezettségre, miként azt Gander, Proyer, Ruch és Wyss (2012) viszonylag magasan kvalifikált női mintán ( $\mathrm{n}=887)$ végzett vizsgálata igazolja. A szerzők rámutatnak: a dolgozók erősségeire alapozott intervenciók - fenntartva az ambíciót és az érdeklődést - előmozdítják mind a munkahelyi elégedettséget, mind az egyéni és csoportteljesítményt.

Mivel mint személyiségjellemző legalább két fő faktorra, egy motivációsérzelmi és egy kognitív faktorra bomlik, így a remény az élményszintú önismeretfejlesztés és a kognitív módszerek útján is hozzáférhetó. Szituatív vonatkozásai főként akkor juthatnak szerephez, amikor új élethelyzet elóállásakor új célokat kell kitúzni. A személyes hatóerő fejlesztésére és az újszerú helyzetmegoldások kidolgozására irányuló remény-tréningek kiválóan beilleszthetők a kognitív terápiás folyamatokba. Időbeli beágyazottságának köszönhetóen, az élettörténeti újrastrukturálás és jelentésadás révén a remény a narratív megközelítés által is befolyásolható (McIlveen, 2014). Az intervenciók elsődlegesen és célszerúen a magas kockázati csoportokra kell irányuljanak annak érdekében, hogy populációszinten is meggyőzően hatékonyak lehessenek.

Összehasonlítható eredmények egységesen alkalmazott mérőeszközöket kívánnának. Jelenleg eltéró elméleti alapokon különféle vizsgálati eszközöket használnak. A remény gyógyulásban betöltött szerepének pontosabb leírása érdekében további hosszmetszeti kutatások szükségesek. A remény empirikus vizsgálatának hazai távlatait kínálja mind a párkapcsolati kommunikáció területe (Kis és Kovács, 2013), mind az egészség-, illetve beteg- 
ségmagatartás klinikai kutatása (Berkes, 2012), mind a népegészségügyi kockázatot jelentő megbetegedések, azok közül is elsőrenden a depresszió létrejöttének multidimenzionális, multifaktoriális szemlélete (Bugán és Margitics, 2006).

Kopp Mária (1997a) közel két évtizeddel ezelőtt felhívta a figyelmet a reménytelen lelkiállapot mint pszichoszociális kockázati tényező megelőzésének fontosságára, népegészségügyi programok kiemelt céljainak egyikére. Bár a remény pozitív szerepe egyéni krízisszituációkban is alátámasztást nyert, társas viszonylatban, homogén csoporthatások közepette még inkább hatékony.

\section{6. Összefoglalás}

A remény, mint a személy bizonyos jelentős célra tekintettel kialakított, önmagára vonatkozó hiedelme és megküzdési viselkedése, az egészség egyik összetevője, amely fogalmat testi, lelki, társas és spirituális egyensúlyként értelmezünk. A remény a spiritualitás dimenzióján belül helyezhetó el, és felfogható a fizikai, mentális és szociális jóllét elérésének egyik forrásaként és stratégiájaként.

A cél, amelyre a remény irányul, az egyén aktuális élethelyzetének, egészségi állapotának, értékrendjének, élettörténetének, társas közegének és transzcendens kapacitásának összefüggésében rajzolódik ki. A cél tényleges elérésére törekvés mértéke a reményteliség fogalmában foglalható össze, amely a lehetséges célelérési utak realizálhatóságának és a becsült személyes hatóerőnek a függvénye.

Remény és reménytelenség nem egyszerúen egymás ellentétei, nem egyetlen dimenzió két végpontja. A személy, aki tudatában van személyes hatóerejének és problémamegoldó képességének (reménység spektrum), egyidejúleg rendelkezhet negatív gondolatokkal és elvárásokkal jövendőjére vonatkozóan (reménytelenség spektrum). A két konstruktum időbeli fókusza is eltérő. A reménytelenség a jövőt vetíti előre a személy diszfunkcionális attitúdjének vagy maladaptív sémáinak függvényében, míg a remény a jelen és a múlt sikeres céleléréseinek tapasztalatára alapoz. Az élet végi reménytelenség (Sullivan, 2003) sem egyszerúen a remény hiánya, hanem ragaszkodás a remény korábbi, immár elveszett tárgyaihoz. A remény tehát a reménytelenség idején, például gyógyíthatatlan betegség kilátásaira tekintettel mutatkozik meg teljes diverzitásában, amikor az el nem érhető cél, például gyógyulás helyett a személy új célokat képes kitúzni, tehát bízik a gondoskodás elfogadására, a bensőségesség megélésére való képességében, vagy egy békés eltávozás esélyében.

A remény lélektani jelentőségét fokozza multidimenzionális jellege. Társas gyökerei arra mutatnak rá, hogy akár a neveltetés során (család, iskola, 
gyülekezet), akár későbbi jelentős életesemények idején előálló társas hatások által (kórházi-terápiás közösség, civil egyesületi, egyházi aktivitások) erősíthető, és így a személyes azonosságtudat elemévé válhat. A remény fejleszthető képesség, amelynek tartóssága és kiterjedtsége növelhető (Seligmann, 2008).

A remény fogalmának megragadása összetett feladat. A különféle szempontok mentén történő konceptualizálás nyomán szükségszerúen vetődik fel egy integratív definíció igénye. Amennyiben az eddigi eredmények alapján a különféle sajátosságokat egyetlen elméleti modellbe kívánnánk foglalni, úgy határozhatnánk meg e lélektani konstruktumot, hogy a remény viselkedésben megnyilvánuló célelérő képesség, amikor is az egyén motivációja mindent megelőzóen egy vágyott, számára létfontosságúnak ítélt célra irányul. Egyrészről tehát egy humán incentív érték. Az életút során folyamatosan szerephez jut, mint az egészséges fejlődés feltétele, az adaptív múködés előmozdítója. Ugyanakkor létrejötte és tartóssága a külső kontroll figyelembe vételét igényli, szintje a társas környezetben elérhető támogató kapcsolatok függvényében változhat. Összességében: A remény olyan dinamikus személyiségvonás és személyközi kölcsönhatások révén generált belsö energia, amely a magát egy közösség vagy egy megbízható kapcsolat részesének tekintő egyént kilátástalannak látszó élethelyzetekben megküzdésre sarkallja.

A remény lélektani jelentőségének hangsúlyozása egy eddig kevésbé preferált ponton nyit utat a népesség lelki-testi és szociális-spirituális egészségi állapotának és életminőségének javításához. Módszerbeli gazdagodást hozva teheti hatékonyabbá a megelőzés eszközeit, társadalmi méretekben is érzékelhető változást mozdítva elő.

\section{Irodalomjegyzék}

Abi-Hashem, N. (2001). Rediscovering hope in American psychology. American Psychologist, 56(1), 85-86.

Abramson, L.Y., Metalsky, G.I., \& Alloy, L.B. (1989). Hopelessness depression: A theorybased subtype of depression. Psychological Review, 96(2), 358-372.

Abramson, L.Y., Seligman, M.E.P., \& Teasdale, J.D. (1978). Learned helplessness in humans: Critique and reformulation. Journal of Abnormal Psychology, 78(1), 49-74.

Affleck, G., \& Tennen, H. (1996). Construing benefits from adversity: Adaptational significance and dispositional underpinnings. Journal of Personality, 64(4), 899-922.

Alarcon, G.M., Bowling, N.A., \& Khazon, S. (2013). Great expectations: A meta-analytic examination of optimism and hope. Personality and Individual Differences, 54(7), 821-827.

Al-Mabuk, R.H., Enright, R.D., \& Cardis, P.A. (1995). Forgiveness education with parentally lovedeprived late adolescents. Journal of Moral Education, 24(4), 427-444.

Andrejkovics, M., Gasparik, É., Bokor, P., \& Frecska, E. (2013). Az orvoslás és a pszichoterápia új paradigmája: A bio-pszicho-szocio-spirituális (bpss) modell. Pszichoterápia, 22(2), 93-99. 
Arnau, R.C., Rosen, D.H., Finch, J.F., Rhudy, J.L., \& Fortunato, V.J. (2007). Longitudinal effects of hope on depression and anxiety: A latent variable analysis. Journal of Personality, $75(1), 43-64$.

Aspinwall, L.G., \& Taylor, S.E. (1997). A stitch in time: self-regulation and proactive coping. Psychological Bulletin, 121(3), 417-436.

Averill, J.R., Catlin, G., \& Cohn. K.K. (1990). Rules of hope. New York, Springer. Idézi Lipps, B. \& Huppmann, G. Zur medizinischen Psychologie der Hoffnung. In G. Huppmann, \& B. Lipps (Hg.), Prolegomena einer medizinischen Psychologie der Hoffnung (189-199). Würzburg: Königshausen \& Neumann

Bagdy, E. (1996). A transzperszonális pszichológia szellemi horizontja. Pszichoterápia, 5(2), 79-86.

Bagdy, E. (2014). Mentális egészség és spiritualitás. Magyar Pszichológiai Szemle, 69(4/1), 643-663.

Balajti, I., Vokó, Z., Ádány R., \& Kósa, K. (2007). A koherencia-érzés mérésére szolgáló rövidített kérdőív és a lelki egészség (GHQ-12) kérdőív magyar nyelvú változatainak validálása. Mentálhigiéné és Pszichoszomatika, 8(2), 147-161.

Bandura, A. (1977). Self-efficacy. Toward a unifying theory of behavior change. Psychological Review, 84(2), 191-215.

Beck, A.T., Weissman, A., Lester, D., \& Trexler, L. (1974). The measurement of pessimism: The Hopelessness Scale. Journal of Consulting and Clinical Psychology, 42(6), 861-865.

Bérdi, M., \& Köteles, F. (2010). Az optimizmus mérése: az Életszemlélet Teszt átdolgozott változatának (LOT-R) pszichometriai jellemzői hazai mintán. Magyar Pszichológiai Szemle, 65(2), 273-294.

Berkes, T. (2012). A kardiovaszkuláris megbetegedések prevenciója és rehabilitációja. In Urbán, R., Demetrovics, Zs., Rigó, A., \& Oláh, A. (Szerk.), Az egészségpszichológia elmélete és alkalmazása II. Klinikai egészségpszichológia (53-85). Budapest: ELTE Eötvös Kiadó

Bernardo, A.B. (2010). Extending hope theory: Internal and external locus of trait hope. Personality and Individual Differences, 49(8), 944-949.

Bibó, I. (2004). Válogatott tanulmányok. Budapest: Magvető Kiadó

Bodor, P., Andrejkovics, M., \& Frecska, E. (2015). Spiritualitás a medicinában. In Füredi, J., \& Németh, A. (Szerk.), A pszichiátria nagy kézikönyve (111-116). Budapest: Medicina

Brodda, K. (2006). Zur Deutung und Bedeutung von Hoffnung. In G. Huppmann, \& B. Lipps (Hg.), Prolegomena einer medizinischen Psychologie der Hoffnung (23-45). Würzburg: Königshausen \& Neumann

Bryant, F.B., \& Cvengros, J.A. (2004). Distinguishing hope and optimism: Two sides of a coin, or two separate coins? Journal of Social and Clinical Psychology, 23(2), 273-302.

Buda, B., \& Kopp. M. (2001). Magatartástudományok. Budapest: Medicina Könyvkiadó Zrt.

Bugán, A., Margitics, F. (2006). A szubklinikus depressziós tünetegyüttes háttértényezői főiskolai hallgatóknál. In Bugán, A. (Szerk.), A kapcsolati egyensúlyok szerepe az egészséges alkalmazkodásban (287-360). Budapest: Didakt Kiadó

Chimich, W.T., \& Nekolaichuk, Ch.L. (2004). Exploring the links between depression, integrity, and hope in the elderly. The Canadian Journal of Psychiatry, 49(7), 428-433.

Curry, L.A., Snyder, C.R., Cook, D.L., Ruby, B.C., \& Rehm, M. (1997). The role of hope in student-athlete academic and sport achievement. Journal of Personality and Social Psychology, 73(6), 1257-1267.

Csíkszentmihályi, M. (2000). A flow - az áramlat. A tökéletes élmény pszichológiája. Budapest: Akadémiai Kiadó

Davidson, C.L., Wingate, L.R., Rasmussen, K.A., \& Slish, M.L. (2009). Hope as a predictor of interpersonal suicide risk. Suicide and Life-Threatening Behavior, 39(5), 499-507. 
Deci, E.L., \& Ryan, R.M. (2004). Oberview of self-determination theory: An organismic dialectical perspective. In E.L. Deci, \& R.M. Ryan (Eds.), Handbook of Self-determination Research (3-33). Rochester: The University of Rochester Press

Diener, E., Lucas, R.E., \& Oishi, S. (2005). Subjective well-being. In C.R. Snyder, \& S.J. Lopez (Eds.), Handbook of Positive Psychology (63-73). Oxford: University Press

Du, H., \& King, R.B. (2013). Placing hope in self and others: Exploring the relationships among self-construals, locus of hope, and adjustment. Personality and Individual Differences, 54(3), 332-337.

Du, H., Bernardo, A.B.I., \& Yeung, S.S. (2015). Locus-of-hope and life satisfaction: The mediating roles of personal self-esteem and relational self-esteem. Personality and Individual Differences, 83(1), 228-233.

Dufault, K., \& Martocchio, B.C. (1985). Symposium on compassionate care and the dying experience. Hope. Its spheres and dimensions. Nursing Clinics of North America, 20(2), 379-391.

Elliot, J. (2012). Hope. In M.R. Cobb, Ch. M. Puchalski, \& B. Rumbold (Eds.), Oxford textbook of spirituality in healthcare (119-125). Oxford: OUP

Elliott, T.R., Witty, T.E., Herrick, S., \& Hoffman, J.T. (1991). Negotiating reality after physical loss: Hope, depression, and disability. Journal of Personality and Social Psychology, 61(4), 608-613.

Erickson, R.C., Post, R.D., \& Paige, A.B. (1975). Hope as a psychiatric variable. Journal of Clinical Psychology, 31(2), 324-330.

Erikson, E.H. (1968). Identity: Youth and crisis. New York - London: Norton

Erikson, E.H. (1991). A fiatal Luther és más írások. Budapest: Gondolat

Esteves, M., Scoloveno, R.L., Mahat, G., Yarcheski, A., \& Scoloveno, M.A. (2013). An integrative review of adolescent hope. Journal of Pediatric Nursing, 28(2), 105-113

Farran, C.J., Herth, K.A., \& Popovich, J.M. (1995). Hope and hopelessness: Critical clinical constructs. Thousand Oaks, CA: Sage, idézi Snyder, C.R. (2000a). Journal of Social and Clinical Psychology, 19(1), 11-28.

Farran, C.J., Herth, K.A., \& Popovich, J.M. (1999). Hoffnung und Hoffnungslosigkeit. Konzepte für Pflegeforschung und -praxis. Wiesbaden: Ullstein Medical

Feldman, D.B., \& Kubota, M. (2015). Hope, self-efficacy, optimism, and academic achievement: Distinguishing constructs and levels of specificity in predicting college grade-point average. Learning and Individual Differences, 37(1), 210-216.

Fleeson, W. (2004). Moving personality beyond the person-situation debate: the challenge and the opportunity of within-person variability. Current Directions in Psychological Science, 13(2), 83-87.

Folkman, S. (1997). Positive psychological states and coping with severe stress. Social Science $\mathcal{E}$ Medicine, 45(8), 1207-1221.

Forstmeier, S., Uhlendorff, H., \& Maercker, A. (2005). Diagnostik von Ressourcen im Alter. Zeitschrift für Gerontopsychologie \& -psychiatrie, 18(4), 227-257.

Franke-Lompa, C. (2006). Hoffnung in der Therapie von Krebspatienten. In G. Huppmann, \& B. Lipps (Hg.), Prolegomena einer medizinischen Psychologie der Hoffnung (259-262). Würzburg: Königshausen-Neumann

Frankl, V.E. (1982). Trotzdem Ja zum Leben sagen. München: dtv

Frede, U. (2006). Förderung von Hoffnung durch Pychodrama-Therapie. In G. Huppmann, \& B. Lipps (Hg.), Prolegomena einer medizinischen Psychologie der Hoffnung (333-353). Würzburg: Königshausen-Neumann

Freedman, S.R., \& Enright, R.D. (1996). Forgiveness as an intervention goal with incest survivors. Journal of Consulting and Clinical Psychology, 64(5), 983-992. 
Fülöp, É., \& László, J. (2011). Érzelmek a valós csoportközi konfliktusokban - A csoportközi érzelmek történelmi lehorgonyzása. Magyar Pszichológiai Szemle, 66(3), 467-485.

Fülöp, É., Péley, B., \& László, J. (2011). A történelmi pályához kapcsolódó érzelmek modellje magyar történelmi regényekben. Pszichológia, 31(1), 47-62.

Gander, F., Proyer, R.T., Ruch, W., \& Wyss, T. (2012). The good character at work: an initial study on the contribution of character strengths in identifying healthy and unhealthy work-related behavior and experience patterns. International Archives of Occupational and Environmental Health, 85(8), 895-904.

Gestel-Timmermans, H. van, Bogaard, J. van den, Brouwers, E., Herth, K., \& Nieuwenhuize, C. van (2010). Hope as a determinant of mental health recovery: a psychometric evaluation of the Herth Hope Index - Dutch version. Scandinavian Journal of Caring Sciences, 24(S1), 67-74.

Gilman, R., Dooley, J., \& Florell, D. (2006). Relative levels of hope and their relationship with academic and psychological indicators among adolescents. Journal of Social and Clinical Psychology, 25(2), 166-178.

Glawischnig-Goschnik, M. (2010). „Glaube, Liebe, Hoffnung“ Verbales, Nonverbales und Musikalisches in Grenzbereichen der CL-Versorgung. Psychiatrie und Psychotherapie, 6(4), 197-201.

Gottschalk, L.A. (1974). A Hope Scale applicable to verbal samples. Archives of General Psychiatry, 30(6), 779-785.

Gottschalk, L.A. (1985). Hope and other deterrents to illness. American Journal of Psychotherapy, 39(4), 515-524.

Hajnal, Á., Tóth, M.D., Székely, A., \& Purebl, Gy. (2013). Stigmatizál-e a depresszió? A Depresszió Stigma Kérdőív. In Susánszky, É. \& Szántó, Zs. (Szerk.), Magyar lelkiállapot 2013 (175-184). Budapest: Semmelweis Kiadó

Halama, P. \& Dedová, M. (2007). Meaning in life and hope as predictors of positive mental health: Do they explain residual variance not predicted by personality traits? Studia Psychologica, 49(3), 191-200.

Hammelstein, Ph., \& Roth, M. (2002). Hoffnung - Grundzüge und Perspektiven eines vernachlässigten Konzeptes. Zeitschrift für Differentielle und Diagnostische Psychologie, 23(2), 191-203.

Hasson-Ohayon, I., Braun, M., Galinsky, D., \& Baider, L. (2009). Religiosity and hope: A path for women coping with a diagnosis of breast cancer. Psychosomatics, 50(5), 525-533.

Hebl, J.H., \& Enright, R.D. (1993). Forgiveness as a psychotherapeutic goal with elderly females. Psychotherapy, Theory, Research, Practice, Training, 30(4), 658-667.

Hellman, Ch.M., Pittman, M.K., \& Munoz, R.T. (2013). The first twenty years of the will and the ways: An examination of score reliability distribution on Snyder's Dispositional Hope Scale. Journal of Happiness Studies, 14(3), 723-729.

Herth, K. (1991). Development and refinement of an instrument to measure hope. Scholarly Inquiry for Nursing Practice: An International Journal, 5(1), 39-51.

Herth, K. (1992). Abbreviated instrument to measure of hope: development and psychometric evaluation. Journal of Advanced Nursing, 17(10), 1251-1259.

Hinds, P.S. (1984). Inducing a definition of 'hope' through the use of grounded theory methodology. Journal of Advanced Nursing, 9(4), 357-362.

Hinds, P.S. (1988). Adolescent hopefulness in illness and health. Advances in Nursing Science, 10(3), 79-88.

Hirsch, J.K., Webb, J.R., \& Jeglic, E.L. (2011). Forgiveness, depression, and suicidal behavior among a diverse sample of college students. Journal of Clinical Psychology, 67(9), 896-906. 
Hirschi, A. (2014). Hope as a resource for self-directed career management: Investigating mediating effects on proactive career behaviors and life and job satisfaction. Journal of Happiness Studies, 15(6), 1495-1512.

Hirschi, A., Abessolo, M., \& Froidevaux, A. (2015). Hope as a resource for career exploration: Examining incremental and cross-lagged effects. Journal of Vocational Behavior, 86(1), 38-47.

Horton, T.V., \& Wallander, J.L. (2001). Hope and social support as resilience factors against psychological distress of mothers who care for children with chronic physical conditions. Rehabilitation Psychology, 46(4), 382-399.

Howell, A.J., \& Larsen, D.J. (2015). Understanding other-oriented hope: An integral concept within hope studies. Heidelberg-New York-Dordrecht-London: Springer

Huen, J.M.Y., Ip, B.Y.T., Ho, S.M.Y., \& Yip, P.S.F. (2015). Hope and hopelessness: The role of hope in buffering the impact of hopelessness on suicidal ideation. PLOS ONE, 10(6), e0130073.

Huppmann, G. (2006). Vorwort. In G. Huppmann, \& B. Lipps (Hg.), Prolegomena einer medizinischen Psychologie der Hoffnung (11-19.). Würzburg: Königshausen - Neumann

Irving, L.M., Snyder, C.R., Crowson Jr., J.J. (1998). Hope and coping with cancer by college women. Journal of Personality, 66(2), 195-214.

Izard, C.E. (1981). Die Emotionen des Menschen. Weinheim: Beltz. Idézi Lipps, B. \& Huppmann, G. (2006). Zur medizinischen Psychologie der Hoffnung. In G. Huppmann, \& B. Lipps (Hg.), Prolegomena einer medizinischen Psychologie der Hoffnung (189-199). Würzburg: Königshausen-Neumann

Jackson, W.T., Taylor, R.E., Palmatier, A.D., Elliott, T.R., \& Elliott, J.L. (1998). Negotiating the reality of visual impairment: Hope, coping, and functional ability. Journal of Clinical Psychology in Medical Settings, 5(2), 173-185.

Kis, M. \& Kovács, J. (2010). A bosszú pszichológiai összetevői. Mentálhigiénéés Pszichoszomatika, 11(2), 129-150.

Kis, M. \& Kovács, J. (2013). Jóvátételi mintázatok hatása a jóvátételi igényekre és a megbocsátásra közeli kapcsolatokban. Magyar Pszichológiai Szemle, 68(4), 687-712.

Koehn, C., O'Neil, L., \& Sherry, J. (2012). Hope-focused interventions in substance abuse counselling. International Journal of Mental Health and Addiction, 10(3), 441-452.

Koenig, H., Pargament, K.I., Nielsen, J. (1998): Religious coping and health status in medically ill hospitalized older adults. Journal of Nervous \& Mental Disease, 186(9), 513521.

Kopp, M. (1997a). A reménytelenség szerepe a betegségek létrejöttében, ennek jelentősége a mai magyar társadalomban. Kórház, 4(3), 4-10.

Kopp, M. (1997b). Testi és lelki egészségünk összefüggései. Praxis, 6(11), 37-45.

Kopp, M., Skrabski, Á., \& Czakó, L. (1990). Összehasonlító mentálhigiénés vizsgálatokhoz ajánlott módszertan (Országos reprezentatív felmérés alapján). Végeken, 2(2), 4-24.

Korner, I.N. (1970). Hope as a method of coping. Journal of Consulting and Clinical Psychology, 34(2), 134-139.

Kulcsár, Zs. (1998). Egészségpszichológia. Budapest: ELTE Eötvös Kiadó

Kulcsár, Zs. (2005). A társas interakciók pszichológiai hatásai és agyi mechanizmusai. Egy hipotézis körvonalai. Társas támogatás. In Kulcsár, Zs. (Szerk.), Teher alatt... Pozitív traumafeldolgozás és poszttraumás személyiségfejlődés. Szöveggyújtemény (315-393). Budapest: Trefort Kiadó

Kulcsár, Zs. (2009). Traumafeldolgozás és vallás. Budapest: Trefort Kiadó

Kulcsár, Zs., Rózsa, S., \& Reinhardt, M. (2006). A poszttraumás növekedés feltételei és empirikus vizsgálata. Budapest: Trefort Kiadó 
Kwon, P. (2000). Hope and dysphoria: The moderating role of defense mechanisms. Journal of Personality, 68(2), 199-233.

Kwon, P. (2002). Hope, defense mechanisms, and adjustment: Implications for false hope and defensive hopelessness. Journal of Personality, 70(2), 207-231.

Langer, E. (2005). Well-being. Mindfulness versus positive evaluation. In C.R. Snyder, \& S.J. Lopez (Eds.), Handbook of Positive Psychology (214-230). Oxford: University Press

László, J., \& Fülöp, É. (2010). A történelem érzelmi reprezentációja történelemkönyvekben és naiv elbeszélésekben. Történelemtanítás, (XLV.) Új folyam I(3). Letöltve: 2014. 12. 05-én: http://www.folyoirat.tortenelemtanitas.hu/wp-content/uploads/2010/10/01_03_02laszlo-fulop.pdf

László, J. (2008). Narratív pszichológia, Pszichológia, 28(4), 301-317.

Lazarus, R.S. (1999). Hope: an emotion and a vital coping resource against despair. Social Research, 66(2), 653-678.

Lindén, K., \& Tingbaeck, M. (2006). Promoting sence of coherence in parasuicidal patients. Gothenburg: Institut of Care and Health Science. Letöltve: 2016. 01. 21-én: https:// gupea.ub.gu.se/bitstream/2077/2523/1/opponentex.pdf

Lipps, B., \& Huppmann, G. (2006a). Zur medizinischen Psychologie der Hoffnung. In: G. Huppmann \& B. Lipps (Hg.), Prolegomena einer medizinischen Psychologie der Hoffnung (189-199). Würzburg: Königshausen-Neumann

Lipps, B., \& Huppmann, G. (2006b). Instrumente zur Messung von Hoffnung - eine kritische Synopsis. In G. Huppmann \& B. Lipps (Hg.), Prolegomena einer medizinischen Psychologie der Hoffnung (201-206). Würzburg: Königshausen-Neumann

Lopes, M.P., Cunha, M.P. (2008). Who is more proactive, the optimist or the pessimist? Exploring the role of hope as a moderator. The Journal of Positive Psychology, 3(2), 100-109.

Lopez, A.D., Mathers, C.D., Ezzati, M., Jamison, D.T., \& Murray, Ch.J.L. (2006). Global and regional burden disease and risk factors, 2001. systhematic analysis of population health data. Lancet, 367(9524), 1747-1757.

Lynch, W.F. (1965). Images of Hope. Garamony/Tnchemah, Baltimore, New York, idézi Stephenson, Ch. (1991). The concept of hope revisited for nursing. Journal of Advanced Nursing, 16(12), 1456-1461.

MacLeod, A.K., Rose, G.S., \& Williams, J.M.G. (1993). Components of hopelessness about the future in parasuicide. Cognitive Therapy and Research, 17(5), 441-455.

Magaletta, P.R., \& Oliver, J.M. (1999). The hope construct, will and ways: Their relative relations with self-efficacy, optimism, and general well-being. Journal of Clinical Psychology, 55(5), 539-551.

Magyaródi, T. (2012). Pozitív pszichológiai témák megjelenése a magyar szakfolyóiratokban és könyvekben (2000-2011). Magyar Pszichológiai Szemle, 67(1), 183-191.

Martos, T. \& Kézdy, A. (2007). A vallásosság szerepe a személyes célok rendszerében. In Horváth-Szabó, K. (Szerk.), Vallásosság és személyiség (134-157). Piliscsaba: Pázmány Péter Katolikus Egyetem, BTK

Martos, T. (2013). Életcélok összefüggése a lelki egészséggel és a párkapcsolatokról alkotott vélekedéssel. In Susánszky, É. \& Szántó, Zs. (Szerk.), Magyar lelkiállapot 2013 (77-88). Budapest: Semmelweis Kiadó

Martos, T., Lakatos, Cs. \& Tóth-Vajna, R. (2014). A Remény Skála magyar változatának (AHS-H) pszichometriai jellemzői. Mentálhigiéné és Pszichoszomatika, 15(3), 187-202.

McCullough, M.E., Worthington Jr., E.L., \& Rachal, K.C. (1997). Interpersonal forgiving in close relationships. Journal of Personality and Social Psychology, 73(2), 321-336.

McIlveen, P. (2014). Hope - narratives as a chaos theory of career intervention for failure. Australian Journal of Career Development, 23(1), 37-43. 
Miller, J.F. (1989). Hope-inspiring strategies of the critically ill. Applied Nursing Research, 2(1), 23-29.

Miller, J.F., \& Powers, M.J. (1988). Development of an istrument to measure hope. Nursing Research, 37(1), 6-10.

Moser, U. (2000). Identität, Spiritualität und Lebessinn. Studien zur Theologie und Praxis der Seelsorge 42, Würzburg: Echter

Nagy, H. \& Oláh, A. (2012). A pozitív pszichológia hozzájárulása a megküzdés értelmezéséhez. A személyiség protektív faktorai. In Demetrovics, Zs., Urbán, R., Rigó A., \& Oláh, A. (Szerk.) Az egészségpszichológia elmélete és alkalmazása I. (45-67). Budapest: ELTE Eötvös Kiadó

Nekolaichuk, C.L., Jevne, R.F., \& Maguire, T.O. (1999). Structuring the meaning of hope in health and illness. Social Science \& Medicine, 48(5), 591-605.

Nowotny, M.L. (1989). Assessment of hope in patients with cancer: development of an instrument. Oncology Nursing Forum, 16(1), 57-61.

Obayuwana, A.O., \& Carter, A.L. (1982). The anatomy of hope. Journal of the National Medical Association, 74(3), 229-234.

Oláh, A. (2004). Mi a pozitívuma a pozitív pszichológiának? Iskolakultúra, 2004(11), 39-47.

Oláh, A. (2005). Érzelmek, megküzdés, optimális élmény. Budapest: Trefort Kiadó

Ong, A.D., Edwards, L.M., \& Bergemann, C.S. (2006). Hope as a source of resilience in later adulthood. Personality and Individual Differencies, 41(7), 1263-1273.

Pally, R. (2000). Az agy-lélek kapcsolat. Budapest: Animula

Perczel Forintos, D., Sallai, J., \& Rózsa, S. (2001). A Beck-féle reménytelenség skála pszichometriai vizsgálata. Psychiatria Hungarica, 16(6), 632-643.

Pergament, K.I., Koenig, H.G., Tarakeshwar, N., \& Hahn, J. (2004). Religious coping methods as predictors of psychological, physical and spiritual outcomes among medically ill elderly patients: A two-year longitudinal Study. Journal of Health Psychology, 9(6), 713-730.

Peterson, C., \& Park, N. (2004). Introdution to a "Manual of the Sanities”. In C. Peterson, \& M.E.P. Seligman (Eds.), Character strengths and virtues: A handbook and classification (3-32). New York: Oxford University Press

Piedmont, R.L. (1999). Does spirituality represent the sixth factor of personality? Spiritual transcendence and the five factor model. Journal of Personality, 67(6), 985-1013.

Proyer, R.T., Ruch, W., \& Buschor, C. (2013). Testing strengths-based interventions: A preliminary study on the effectiveness of a program targeting curiosity, gratitude, hope, humor, and zest for enhancing life satisfaction. Journal of Happiness Studies, 14(1), 275-292.

Rand, K.L. (2009). Hope and optimism: Latent structures and influences on grade expectancy and academic performance. Journal of Personality, 77(1), 231-260.

Rand, K.L., Martin, A.D., \& Shea, A.M. (2011). Hope, but not optimism, predicts academic performance of law students beyond previous academic achievement. Journal of Research in Personality, 45(6), 683-686.

Rustøen, T. (1995). Hope and quality of life, two central issues for cancer patients: a theoretical analysis. Cancer Nursing, 18(5), 355-361.

Rye, M.S., Loiacono, D.M., Folck, C.D., Olszewski, B.T., Heim, T.A., \& Madia, B.P. (2001). Evaluation of the psychometric properties of two forgiveness scales. Current Psychology: Developmental, Learning, Personality, Social, 20(3), 260-277.

Scheier, M.F., \& Carver, S.C. (1985). Optimism, coping and health: Assessment and implications of generalized outcome expectancies. Health Psychology, 4(3), 219-247.

Scheier, M.F., Carver, C.S., \& Bridges, M.W. (1994). Distinguishing optimism from neuroticism (and trait anxiety, self-mastery, and self-esteem): A reevaluation of the life orientation test. Journal of Personality and Social Psychology, 67(6), 1063-1078. 
Schrank, B., Bird, V., Rudnick, A., \& Slade, M. (2012). Determinants, self-management strategies and interventions for hope in people with mental disorders: Systematic search and narrative review. Social Science and Medicine, 74(4), 554-564.

Schrank, B., Stanghellini, G., \& Slade, M. (2008). Hope in psychiatry: a review of the literature. Acta Psychiatrica Scandinavica, 118(6), 421-433.

Schrank, B., Woppmann, M.A., Sibitz, I., \& Lauber, Ch. (2011). Development and validation of an integrative scale to assess hope: Development of an integrative hope scale. Health Expectations, 14(4), 417-428.

Schuth, W. (2006). Was könnte "Hoffnung” in der Rezidiv-Situation onkologischer Patientinnen bedeuten? In G. Huppmann, \& B. Lipps (Hg.), Prolegomena einer medizinischen Psychologie der Hoffnung (263-268). Würzburg: Königshausen-Neumann

Schwartz, B. (2000). Self-determination: The tyranny of freedom. American Psychologist, 55(1), 79-88.

Scioli, A, Chamberlin, C., Samor, C., Lapointe, A.B., Campbell, T.L., Macleod, A.R., \& McLenon, J. (1997). A prospective study of hope, optimism, and health. Psychological Reports, 81(3), 723-733.

Scioli, A., MacNeil, S., Partridge, V., Tinker, E., \& Hawkins, E. (2012). Hope, HIV and health: A prospective study. AIDS Care, 24(2), 149-156.

Seemann, H. (2006). Hoffnung im Alter - eine Fallvignette. In G. Huppmann, \& B. Lipps (Hgrs.), Prolegomena einer medizinischen Psychologie der Hoffnung (239-242). Würzburg: Königshausen-Neumann

Seligman, M.E.P. (2008). Autentikus életöröm. A teljes élet titka. Győr: Laurus Kiadó

Seligman, M.E.P. (2011). Fluorish - élj boldogan! A boldogság és jóllét radikálisan új értelmezése. Budapest: Akadémiai Kiadó

Seligman, M.E.P., \& Csíkszentmihályi, M. (2000). Positive psychology: An introduction. American Psychologist, 55(1), 5-14.

Sharabi, A., Levi, U., \& Margalit, M. (2012). Children's loneliness, sense of coherence, family climate, and hope: Developmental risk and protective Factors. The Journal of Psychology: Interdisciplinary and Applied, 146(1-2), 61-83.

Shorey, H.S., Little, T.D., Snyder, C.R., Kluck, B., \& Robitschek, C. (2007). Hope and personal growth initiative: A comparison of positive, future-oriented constructs. Personality and Individual Differences, 43(7), 1917-1926.

Smedes, L.B. (1998): Stations on the journey from forgiveness to hope. In E.L. Worthington (Ed.), Dimensions of forgiveness: Psychological research and theological perpectives. (341-354). Philadelphia. Templeton Press

Snyder, C.R. (1995). Conceptualizing, measuring, and nurturing hope. Journal of Counseling and Development, 73(3), 355-360.

Snyder, C.R. (1996). To hope, to lose, and to hope again. Journal of Personal and Interpersonal Loss, 1(1), 1-16.

Snyder, C.R. (2000a). The past and possible futures of hope. Journal of Social and Clinical Psychology, 19(1), 11-28.

Snyder, C.R. (2000b). Genesis: The birth and growth of hope. In C.R. Snyder, (Ed.), Handbook of Hope. Theory, Measures, Applications (25-38). San Diego, California: Academic Press

Snyder, C.R. (2000c). Hypothesis: There is hope. In C.R. Snyder, (Ed.), Handbook of Hope. Theory, Measures, Applications (3-21). San Diego, California: Academic Press

Snyder, C.R. (2002): Hope theory: Rainbows in the mind. Psychological Inquiry, 13(4), 249-275.

Snyder, C.R., Berg, C., Woodward, J.T., Gum, A., Rand, K.L., Wrobleski, K.K., Brown, J., \& Hackman, A. (2005a). Hope against the cold: Individual differences in trait hope and acute pain tolerance on the cold pressor task. Journal of Personality, 73(2), 287-312. 
Snyder, C.R., Cheavens, J., Sympson, S.C. (1997a). Hope: An individual motive for social commerce. Group Dynamics: Theory, Research, and Practice, 1(2), 107-118.

Snyder, C.R., Harris, C., Anderson, J.R., Holleran, S.A., Irving, L.M., Sigmon, S.T., Yoshinobu, L., Gibb, J., Langelle, C., \& Harney, P. (1991). The will and the ways: development and validation of an individual - differences measure of hope. Journal of Personality and Social Psychology, 60(4), 570-585.

Snyder, C.R., Hoza, B., Pelham, W.E., Rapoff, M., Ware, L., Danovsky, M., Highberger, L., Rubinstein, H., \& Stahl, K.J. (1997b). The development and validation of the children's hope scale. Journal of Pediatric Psychology, 22(3), 399-421.

Snyder, C.R., Rand, K.L., \& Sigmon, D.R. (2005). Hope theory. A member of the positive psychology family. In C.R. Snyder \& S.J. Lopez. (Eds.), Handbook of Positive Psychology, (257-276). Oxford: University Press

Staats, S. (1989). Hope: A comparison of two self-report measures for adults. Journal of Personality Assessments, 53(2), 366-375.

Stanton, A.L., Danoff-Burg, S., Cameron, C., Bishop, M., Collins, C.A., \& Kirk, S.B. (2000). Emotionally expressive coping predicts psychological and physical adjustment to breast cancer. Journal of Consulting and Clinical Psychology, 68(5), 875-882.

Stoner, M.J.H. (1982). Hope and cancer patients. Doctoral dissertation. University of Colorado, (idézi Stoner, M.H. 1988, Measuring hope. In M. Stromborg (Ed.), Instruments for Clinical Nursing practice (133-140). Norwalk: Appleton \& Lange

Stotland, E. (1969). The psyhology of hope. San Francisco: Jossey-Bass, idézi: Erickson, R. C., Post, R.D., \& Paige, A.B. (1975). Hope as a psychiatric variable. Journal of Clinical Psychology, 31, 324-330, valamint Lipps, B., \& Huppmann, G. (2006). Zur medizinischen Psychologie der Hoffnung. In G. Huppmann, \& B. Lipps, (Hg.), Prolegomena einer medizinischen Psychologie der Hoffnung (189-199). Würzburg: Königshausen-Neumann

Sullivan, M.D. (2003). Hope and hopelessness at the end of life. The American Journal of Geriatric Psychiatry, 11(4), 393-405.

Susánszky, É., Szántó, Zs., \& Körmendi, J. (2013). Az egészségi állapot alakulását befolyásoló jövedelmi egyenlőtlenségek objektív és szubjektív mutatói. In Susánszky, É., \& Szántó, Zs. (Szerk.), Magyar lelkiállapot 2013 (51-59). Budapest: Semmelweis Kiadó

Szondy, M. (2006). Optimizmus és egészség. Magyar Pszichológiai Szemle, 61(4), 617-636.

Szondy, M. (2008). Optimizmus, pesszimizmus, egészség és egészségmagatartás. PhD értekezés, Kézirat, Budapest: ELTE

Szondy, M. (2011). Optimizmus, életminőség és pozitív pszichoterápia. Magyar Pszichológiai Szemle, 66(1), 203-223.

Tennen, H., Affleck, G., \& Tennen, R. (2002). Clipped feathers: The theory and measurement of hope. Psychological Inquiry, 13(4), 311-317.

Thoresen, C.E., Harris, A.H.S., Luskin, F. (2000). Forgiveness and health. An unanswered question. In M.E. McCullough, K.I. Pargament, \& C.E. Thoresen (Eds.), Forgiveness: Theory, research, and practice (254-280). New York: Guilford Press

Tiger, L. (1979). Optimism: the biology of hope. New York: Simon \& Schuster, idézi: Scioli, A, Chamberlin, C., Samor, C., Lapointe, A.B., Campbell, T.L., Macleod, A.R., \& McLenon, J. (1997). A prospective study of hope, optimism, and health. Psychological Reports, 81(3), 723-733.

Tomcsányi, T. (2000). Mental health promotion through the dialogue of different philosophies and professions: an interdisciplinary training program in mental health. Mental Health, Religion and Culture, 3(2), 143-155.

Tomcsányi, T., Csáky-Pallavicini, R., Ittzés, G., Semsey, G., \& Török, P. (2006). Health promotion strategy and primary prevention program at Semmelweis University. European Journal of Mental Health, 1(1-2), 25-44. 
Tordai, Z. (2006). A depresszió és a szívbetegség kapcsolatának vizsgálata szívmútéten átesett személyek körében. In Bugán, A. (Szerk.), A kapcsolati egyensúlyok szerepe az egészséges alkalmazkodásban (267-285). Budapest: Didakt Kiadó

Toussaint, L.L., Williams, D.R., Musick, M.A., \& Everson-Rose, S. (2008). Why forgiveness may protect against depression: Hopelessness as an explanatory mechanism. Personality and Mental Health, 2, 89-103.

Tringer, L. (2005). A gyógyitó beszélgetés (3. kiad.). Budapest: Semmelweis Kiadó

Urbán, R. (2001). Útban a magatartásszempontú egészségpszichológia felé: Az egészségmagatartás pszichológiai elemzése. Magyar Pszichológia Szemle, 56(4), 593-622.

Valle, M.F., \& Suldo, S.M. (2004). Further evaluation of the Children's Hope Scale. Journal of Psychoeducational Assessment, 22(4), 320-337.

Valle, M.F., Huebner, E.S., \& Suldo, S.M. (2006). An analysis of hope as a psychological strength. Journal of School Psychology, 44(5), 393-406.

Wong, S.S., Lim, T. (2009). Hope versus optimism in Singaporean adolescents: Contributions to depression and life satisfaction. Personality and Individual Differences, 46(5-6), 648-652.

Worthington Jr., E.L., Witvliet, Ch.O., Pietrini, P., \& Miller, A.J. (2007). Forgiveness, health, and well-being: A review of evidence for emotional versus decisional forgiveness, dispositional forgivingness, and reduced unforgiveness. Journal of Behavioral Medicine, 30(4), 291-302.

Yalom, I.D. (2000). Momma and the Meaning of Life: Tales of Psychotherapy. New York: Harper Collins Publishers

Ziv, N., Chaim, A.B., \& Itamar, O. (2011). The effect of positive music and dispositional hope on state hope and affect. Psychology of Music, 39(1), 3-17.

\title{
Szerzói nyilatkozat
}

A szerző nyilatkozik, hogy esetében nem állnak fenn érdekütközések.

\section{The psychology of hope. A review of theory and empirical research}

\author{
KIS, MÉDEA
}

This paper gives an overview of those international and Hungarian publications that addressed various aspects of the constructs of hope in the past two decades using empirical methods. The differencies between these approaches is briefly described along with the main tendences of psychological researches and therapeutical effectiveness. Hope as an attribute is an expectation for achieving a short term goal which is really precious for an individual and for the future. It also means that the current situation is not satisfactory. Hopefulness can be improved by changing its mental, cognitive, motivational, and environmental components. It has an effect on the level of communication in relationships, on being successful in various fields, e.g. at work or in sports, and most importantly it helps in healing illnesses and posttraumatic stress.

Keywords: hope, hopelessness, empirical researches, practical interventions 